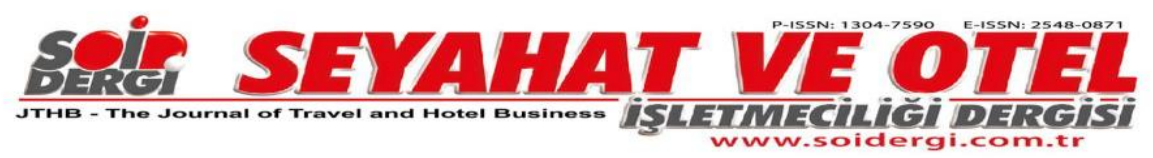

Seyahat ve Otel İşletmeciliği Dergisi/

Journal of Travel and Hospitality Business

Cilt/Vol:18(2),Yıl/ Year: 2021, ss/pp: 450-477.

Gönderim Tarihi/ Received: 09.03.2021

Kabul Tarihi /Accepted:21.06.2021

DOI: $10.24010 /$ soid.893697

Araştırma Makalesi/ Research Article

\title{
Kişilik Tiplerinin Yılmazlığa Etkisinde Duygusal Emeğin Aracılık Rolü: İstanbul Otel İşletmelerinde Bir Uygulama*
}

\section{The mediating role of emotional labor on the effects of personality types on resilience: An application in hotel management in İstanbul}

\author{
Süreyya Akçay \\ Erciyes Üniversitesi \\ Sosyal Bilimler Enstitüsü \\ E-posta: akcaysureyya@gmail.com
}

\author{
Prof.Dr. Muharrem Tuna \\ Ankara Hacı Bayram Veli Üniversitesi \\ Turizm Fakültesi \\ E-posta: muharrem.tuna@hbv.edu.tr
}

\section{Öz}

$\mathrm{Bu}$ araştırmanın amacı, hizmet sektörünün bir kolu olan turizm sektöründe hizmet veren otel işletmelerinin çalışanlarının sahip oldukları yılmazlık özelliğinin, kişilik özellikleriyle ilişkisinde duygusal emeğin aracı rolünü tespit etmektir. Araştırmanın örneklemini, İstanbul'da basit seçkisiz örnekleme yöntemiyle seçilmiş beş yıldızı otel işletmelerinin çalışanları oluşturmaktadır. Toplamda 434 çalışana anket uygulanmıştır. Aracılık modeli kurulmuş ve veriler analiz edilmiştir. Çalışanların kişiliklerinin yılmazlık düzeylerini etkilemesinde duygusal emek çabalarının aracılık etkisi incelenmiş, ilgili analizlerin sonuçlarında, çalışanların duygusal emeğin bazı boyutlarında aracılık etkisi olduğu tespit edilmiştir. Araştırmadan elde edilen bulgular doğrultusunda çeşitli önerilerde bulunulmuştur.

Anahtar Kelimeler: Kişilik, Kişilik Tipleri, Yılmazlık, Duygusal Emek, Otel

\section{Abstract}

The aim of this research is to determine the mediating role of emotional labor in the relationship between the resilience of the employees of the hotel enterprises serving in the tourism sector, which is a branch of the service sector, and their personality traits. The sample of the research consists of the employees of five-star hotels in Istanbul selected by simple random sampling method. A total of 434 employees were surveyed. The mediation model was established and the data analyzed. The mediating effect of emotional labor efforts in the effect of employees' personalities on their resilience levels was examined, and it was determined that there was a mediating effect in some dimensions of emotional labor in the results of the related analyzes. Various suggestions were made in line with the findings obtained from the research.

Key Words: Personality, Personality Types, Resilience, Emotional Labor, Hotel

${ }^{\star}$ Bu makale, Gazi Üniversitesi Sosyal Bilimler Enstitüsü Turizm İşletmeciliği ABD Yüksek Lisans Tezinden üretilmiştir. 


\section{Extended Summary}

\section{Purpose}

The aim of this research is to determine the mediating role of emotional labor in the relationship between the resilience of the employees of the hotel enterprises serving in the tourism sector, which is a branch of the service sector, and their personality traits.

\section{Background}

It is possible to say that the individual differences of the employees are particularly effective in the emotional expressions of their personalities (Barrick \& Mount, 2005; Favoriirbaş \& Yalçın, 2012; Tews \& Glomb, 2004). While personality is an internal protective factor that supports resilience, it is also effective in the formation of emotional labor behavior. On the other hand, it can be said that emotional labor has an effect that reveals resilience behavior by supporting the adaptation efforts that the individual can live in the work environment (Alamur \& Atabay; 2016; Cheung \& Tang, 2010). In this study, the relationship between the "personality types" of hotel employees with stressful, labor-intensive working conditions and the "resilience" traits that enable these individuals to survive in difficult conditions, and the mediating effect of "emotional labor" efforts on this relationship were investigated.

\section{Method}

The sample of the study consists of 434 employees working in five-star hotels selected by simple random sampling method in Istanbul. Data were analyzed using mediation model. The mediating effect of emotional labor efforts on the resilience of employees' personalities was examined. In the analyzes, regression analysis was performed using the bootstrap technique and 5000 resampling. Whether there is a mediating effect is determined by looking at the confidence interval $(\mathrm{Cl})$. If the confidence interval includes a value of zero, it is stated that there is no intermediary effect (MacKinnon et al., 2004).

\section{Findings}

The "openness to experience" personality trait "flexibility of the person to cope with change and difficulties" ( $\mathrm{c}^{\prime}=.00, \mathrm{p}>.05$; point estimate $\left.=.003,95 \% \mathrm{Cl}[-.01, .02]\right)$, "social and family support" (c '=-.02, p>.05; point estimate $=.002,95 \% \mathrm{Cl}[-.01, .02])$, "spiritual support" ( $c^{\prime}=-.03, p>.05$; point estimate $\left.=.004,95 \% \mathrm{Cl}[-.01, .02]\right)$ and "have a goaloriented approach" ( $c^{\prime}=-.02, p>.05$; point estimate $=-.003,95 \% \mathrm{Cl}[-.01, .02]$ ) emotional labor has no mediating role in the effect of resilience on all sub-dimensions. The "conscientiousness" personality trait "flexibility of the person to cope with change and difficulties" ( $c^{\prime}=.02, p>.05$; point estimate $\left.=.004, \% 95 \mathrm{Cl}[-.01, .02]\right)$, "social and family support" ( $c^{\prime}=.03, p>.05$; point estimate $\left.=.003, \% 95 \mathrm{Cl}[-.01, .02]\right)$, "spiritual support" $\left(c^{\prime}=.02, p>.05\right.$; point estimate $\left.=.006, \% 95 \mathrm{Cl}[-.01, .03]\right)$ and "have a goal-oriented approach" ( $c^{\prime}=.00, p>.05$; point estimate $\left.=.005, \% 95 \mathrm{Cl}[-.01, .03]\right)$ emotional labor has no mediating role in the effect of resilience on all sub-dimensions. The "agreeableness" personality trait "flexibility of the person to cope with change and difficulties" $\left(c^{\prime}=.10\right.$, $p<.05$; point estimate $=.004, \% 95 \mathrm{Cl}[-.01, .02])$; "social and family support" ( $c^{\prime}=.13$, $p<.05$; point estimate $=.002, \% 95 \mathrm{Cl}[-.01, .02])$, "spiritual support" $(c$ ' $=.09, p<.05$; point estimate $=.006, \% 95 \mathrm{Cl}[-.02, .03])$ and "have a goal-oriented approach" ( $c^{\prime}=.06, p<.05$; point estimate $=.004, \% 95 \mathrm{Cl}[-.02, .02]$ ) emotional labor has no mediating role in the effect of resilience on all sub-dimensions. The "emotional stability" personality trait "flexibility of the person to cope with change and difficulties" $\left(c^{\prime}=.01, p>.05\right.$; point 
estimate $=.032, \% 95 \mathrm{Cl}[.01, .05])$; "social and family support" ( $c^{\prime}=-.01, p>.05$; point estimate $=.013, \% 95 \mathrm{Cl}[-.003, .03])$, "spiritual support" $\left(c^{\prime}=.03, p>.05\right.$; point estimate $=.021, \% 95 \mathrm{Cl}[-.001, .05])$ and "have a goal-oriented approach" $\left(c^{\prime}=.01\right.$, $p>.05$; point estimate $=.039, \% 95 \mathrm{Cl}[.02, .06]$ ) emotional labor has no mediating role in the effect of resilience on all sub-dimensions. The "extraversion" personality trait "flexibility of the person to cope with change and difficulties" $\left(c^{\prime}=.01, p>.05\right.$; point estimate $=.032, \% 95 \mathrm{Cl}[.01, .05])$ and "have a goal-oriented approach" ( $c^{\prime}=-.02, p>.05$; point estimate $=.039, \% 95 \mathrm{Cl}[.02, .07])$ emotional labor has no mediating role in the effect of resilience on all sub-dimensions. However, emotional labor (deep behavior and naturally felt emotions) appears to have a mediator role in the effect of the "extraversion" sub-dimension on the "social and familial support" sub-dimension of resilience ( $c^{\prime}=.06, p<.05$; point estimate $=.027, \% 95 \mathrm{Cl}[.01, .05]$ ). Emotional labor (deep behavior) has been found to have a mediator role in the effect of the "extraversion" sub-dimension of personality types on the resilience sub-dimension of "spiritual support" ( $c^{\prime}=.11, p<.05$; point estimate $\left.=.035, \% 95 \mathrm{Cl}[.01, .06]\right)$.

\section{Results}

It is known that employees who have the personality traits of extraversion, conscientiousness, and openness to experience also have the characteristic of resilience, therefore, it is recommended that individuals to be employed in managerial positions should be indomitable individuals with the specified personality traits. In addition, it is known that the resilience levels of individuals who display emotional labor are also affected. These results reveal that personality and emotional labor affect the resilience levels of employees. Therefore, in order to protect the mental health of the employees, a positive management policy that supports their resilience, a fair, socially interactive work environment should be created.

\section{Giriş}

Gelişen teknoloji ile hızlı değişen dünya ve bu değişimi yakalamaya çabalayan örgütlerin farklılaşan koşulları, bireylerin davranışlarına yön vermekte, kişilik yapısının gelişmesine, duygularının değişmesine katkı sağlamaktadır. İnsanlar günlük yaşamda sayısız iletişim kurmaktadırlar. Özellikle turizm sektörünün temel yapı taşı insanlar ve kurdukları iletişimdir (Leung ve Law, 2010; Yeni ve Özler, 2016). Farklı insanlarla iletişim turizm çalışanlarının farklı kişisel özelliklere, davranışlara, zihniyetlere de ayak uydurmalarını gerektirir. Her çalışan ya da turist aynı davranmayabilir fakat birkaç kez tekrarlanan iletişim karşılıklı bireylerin özellikleri hakkında fikir sahibi olunmasında etkilidir (Yeung ve Leung, 2007). Burada bireylerin farklı özelliklerini vurgulayan kişilik, turizm sektöründe turizme katılanların, turistik ürüne verdikleri tepkilerden, çalışanların performanslarını yönetmeye, stresle başa çıkma ya da ruhsal iyi oluşlarına kadar pek çok alanda değerlendirme yapılmasına olanak tanımaktadır (Bleidorn ve diğ., 2017; Leung ve Law, 2010).

Kişilik, yılmazlık özelliğinin oluşmasında da etkili olan, bireylerin, problem çözme ve zorlukların üstesinden gelmelerini sağlayarak bu özelliği ortaya çıkaran, sağlığını koruyarak stres, depresyon gibi olumsuzluklardan kolaylıkla baş edebilmelerini destekleyen içsel, koruyucu bir özelliktir (Peng ve diğ., 2012). Bu nedenle hangi kişilik özelliğinin bireylerin yılmazlık düzeylerini etkilediği bilinmelidir (Fayombo, 2010). Çalışanların bireysel farklılıklarının, özellikle de kişiliklerinin duygu gösterimleri üzerinde etkili olduğunu söylemek mümkündür (Barrick ve Mount, 2005; Beğenirbaş ve Yalçın, 2012; Tews ve Glomb, 2004). Kişilik, yılmazlığı destekleyen içsel koruyucu bir faktörken aynı zamanda duygusal emek davranışının oluşmasında da etkilidir. Diğer 
yandan duygusal emeğin bireyin çalışma ortamında yaşayabilecekleri uyum çabalarını destekleyerek yılmazlık davranışını ortaya çıkaran etkiye sahip olduğunu söylenebilir (Biçkes ve diğ., 2014; Cheung ve Tang, 2010). Bu nedenle bu çalışmada, stresli, yoğun emek gerektiren, zorlu çalışma koşulları içeren otel işletmelerinde çalışanların "kişilik tipleri" ile bu çalışanların zorlu koşullar karşısında ayakta kalabilmelerini sağlayan "yılmazlık" özellikleri arasındaki ilişkide "duygusal emek" çabalarının aracılık etkisi incelenmiştir. Bu çalışma, bireylerin kişilik, duygusal emek, yılmazlık ilişkilerinin anlaşılarak benzer riskler altındaki çalışanlara yönelik yapılabilecek önleyici çalışmalara ışık tutacaktır. Ayrıca bu çalışmada ulaşılan sonuçların yorumlanmasıyla, otel işletmelerinde insan kaynakları uygulamaları sürecinde yararlı olabilecek önerilerde bulunulmuştur.

\section{Literatür}

\subsection{Yılmazlık}

Yılmazlık, "psikolojik sağlamlık" (Gizir, 2016; Karaırmak, 2006), "psikolojik dayanıklılık" (Basım ve Çetin, 2011; Kara ve Aydoğan, 2017) gibi çeşitli ifadelerle incelenen ve genel anlamda stresin olumsuz etkileriyle baş etmede ön plana çıkan bir kişilik özelliği olarak değerlendirilmiştir (Connor ve Davidson, 2003). Devam eden çalışmalarda ise yılmazlığın kişi, aile, örgüt, çevre vb. etkileşimleri içeren çok boyutlu dinamik bir süreç olduğu kabul görmüştür (Basım ve Çetin, 2011; Hegney ve diğ., 2007; Masten, 2007). Pozitif örgütsel davranış bağlamında değerlendirilebilen yılmazlık, bireysel ve örgütsel performansı etkileyebilmektedir (Genç, 2014; Youssef ve Luthans, 2007).

Yılmazlık; risk faktörleri, koruyucu faktörler ya da bu faktörlerin meydana getirdiği olumlu sonuçları içeren bütüncül bir yaklaşımdır. Savaş, inmaller, fiziksel engele sahip olma, depresyon ya da alkol kullanımı, yoksulluk gibi olumsuz durumlar risk faktörü olarak değerlendirmektedir. Risk faktörlerinin bilinmesi önleyici uygulamaların planlamasına olanak tanımaktadır (Benard,1991; Gucciardi ve diğ., 2011). Psikolojik refaha ulaşmak için sıkıntılı, stresli olayları hafifletecek koruyucu faktörlerin var olması gerekmektedir. Gerek aile gerekse çevreden gelen sosyal destek kişilerin fiziksel ya da ruhsal yönden zarar görmelerinin önünde bir koruyucu görevi üstlenmekte, bireylerin yaşamında önemli bir yer tutan anne, baba, akraba, arkadaş, eş, öğretmenler, komşular, uzmanlar gibi kişilerin verdiği maddi, duygusal ya da zihinsel destek o bireyin sosyal destek kaynaklarını oluşturmaktadır (Hegney ve diğ., 2007; Kumpfer ve Summerhays, 2006; Terzi, 2008). Piertzak ve Cook (2013) gaziler üzerinde yaptıkları çalışmada, savaş, terör olayları gibi risk faktörlerine maruz kalan gazilerin yaşamda amaç edinmeleri için oluşturulabilecek sosyal destek, topluma uyum gibi psikososyal koruyucu faktörlerin varlığı ile \%69,5'inin yılmaz bireyler olduklarını göstermiştir. Ayrıca, yaşamda hastalık, ekonomik sıkıntılar gibi strese yol açan olaylar karşısında ailenin kurduğu yakın ilişkiler ile karşılaşılan problemleri çözmek için uygulanan stratejiler de uyum sürecine katkı sağlamakta ve olumlu davranışlara yol açmaktadır (McCubbin ve diğ., 2002).

Yılmazlık araştırmacıları yılmazlığı etkileyen faktörleri ortaya koyabilmek için farklı bakış açılarıyla bireylerdeki yılmazlık özelliklerinin neler olduğunu belirlemeye çalışmışlardır. Connor ve Davidson (2003), yılmazlık için normların oluşturulmasını ve klinik tedaviye yanıt olarak yılmazlık düzeylerinin ne ölçüde değiştiğinin değerlendirilmesini amaçlanmıştır. Daha sonra Dong ve arkadaşları (2013), Connor ve Davidson (2003)'ı yılmazlık sürecini göz ardı ettikleri için eleştirerek, bireyin biyolojik, psikolojik ve sosyal faktörlerden etkilendiğini belirtmişler ve algılanan sosyal ve ailesel destek ile yaşamda amaçlı hisler ile ilgili faktörleri içeren kişinin "değişim ve meydan 
okumaya başa çıkma esnekliği, sosyal ve ailesel destek, ruhsal destek ve hedef odaklı yaklaşım" olarak dört faktörlü yapıyla yılmazlık düzeyini belirlemeye çalışmaktadır. Yılmazlık özelliğinin oluşmasında kişinin doğuştan getirdiği kişisel güçlerinin de önemli bir yeri vardır. Bireyler içsel olarak yaşama tutunmak için doğal bir enerjiye sahiptirler. Yaşam amaçları/hedefleri koruyucu faktörler olarak yılmazlığın desteklenmesini sağlamaktadır (Demirbaş, 2010; Richardson, 2002). Ayrıca, birey sosyal bir çevrede yaşamakta aile, arkadaş, okul çevreleri ile kurulan olumlu ilişkilerle zorlukların üstesinden daha kolay gelebilmektedir (Gürgan, 2006). Değişimlere meydan okuyan yılmaz bireyler değişimi ve beraberinde getirdiği stresli yaşam olaylarını, güvenliklerini tehdit eden bir unsur olarak değil de kişisel gelişimi sağlamak için bir fırsat olarak görmektedirler (Terzi, 2008). Diğer yandan, bireyler yaşadıkları sıkıntılardan kurtulabilmenin yolunu inançlarında arayabilmekte, daha yüce bir varlığın olduğuna inanmak iyimserlik ve yardımseverlik yoluyla bireyi daha güçlü hale getirmektedir (Connor ve Davidson, 2003; Richardson, 2002; Hefferon ve Boniwell, 2014: 122).

\subsection{Kişilik}

Kişilik "...bireyin kendi açısından, fizyolojik, zihinsel ve ruhsal özellikleri hakkında bilgisidir" (Eren, 2015: 83). Bu bilgi ile kişilik, bireyin kendini değerlendirmesini, toplum içinde alacağı yeri, görevi tatmin ve çıkar sağlayacak biçimde düzenlemesini sağlamaktadır (Şimşek ve diğ., 2001: 65). Kişilik "bireyi özelliklerinin arkasındaki psikolojik süreçlerle birlikte nitelendiren görece olarak sürekli düşünce, duygu ve davranış kalıplarıdır" (McShane ve von Glinow, 2016: 29). Bu kalıplar içerisinde süreklilik gösteren kişilik, benzer durumlarda benzer davranışların ortaya çıkmasıyla değerlendirilir (İnanç ve Yerlikaya, 2009: 8).

Kişilik çeşitli faktörlerden etkilenmekte, zaman içerisinde gelişim göstermektedir (Bleidorn ve diğ., 2017). Sosyal ortamlarda kişilerin davranışlarına, düşüncelerine, sevinç ya da üzüntü ifade biçimlerine, giyimlerine etki edebilen faktörler kişiliğin oluşumunu da etkilemektedir (Güney, 2013: 188). Kişiliğin, karakter, yetenekler ve mizaç şeklinde üç parçaya ayrılan temel özelliklerden oluştuğu varsayımı da mevcuttur (Özkalp ve Kırel, 2010). Bu özellikler her bireyde farklılık göstermekle birlikte bireylerin kişilik yapılarını açıklamaya çalışan pek çok farklı kişilik kuramlarının ve tipolojilerinin ortaya çıkmasını sağlamıştır. Yönetim, eğitim, psikoloji gibi pek çok alanda en yaygın kullanılan tip, Carl Jung'un tanımladığı kişilik tipleridir (Burger, 2004: 189; Zel, 2006: 36). Başlangıçta Jung, içedönük ve dışadönük olmak üzere iki tip tanımlasa (Jung, 2014) da, dünyada iki tipten farklı tipler de olduğunu ifade etmiştir. Bireyin beden yapısı ile ilgili özellikleri ve kişilik özellikleri arasındaki ilişkiyi inceleyen Kretschmer, üç farklı tip belirlemiş, atletik tipleri, uzun, kaslı beden yapısına sahip, lider olma eğilimi gösteren, sabırlı, sporu sevme gibi kişilik özelliklerini barındıran bireyler olarak tanımlamıştır (Zel, 2006: 43, 44). Kişilik ile ilgili en çok bilinen diğer kuramcılar arasında $A$ ve $B$ kişilik tiplerini tanımlayan Friedman ve Rosenman (Kamaşak ve Bulutlar, 2010), kişiliği ruhsal ve toplumsal bakımdan inceleyen Spranger sayılabilir (Çiğdem, 2011). Kişiliğin pek çok özelliği olması pratikte kişilik eğilimlerinin belirlenmesi için kullanışı olmadığından, araştırmacılar bu özellikleri beş temel kategoride değerlendirme eğiliminde bulunmuşlardır. Bu "Beş Büyük" özellik, birbirinden bağımsız özellikler olup, bireylerin kişiliğinin tarifinde hangi özelliğe sahip olunduğu baskın faktörün belirlenmesiyle tayin edilmektedir (Luthans, 2011: 132). En yaygın temsil olarak beş faktör, dışa dönüklük, duygusal dengelilik/dengesizlik (nevrotiklik), uyumluluk, sorumluk ve deneyime açıklık olarak belirlenmiştir (Atak, 2013; Hefferon ve Boniwell, 2014; McCrae ve Costa, 1987; McCrae ve John, 1992). Burada dişa dönüklük; hırslı, tutkulu ve baskın tipler olarak tanımlanmıştır. Duygusal dengelilik, olumlu psikolojik uyum ile ifade edilen bir kişilik özelliğidir. Uyumluluk; işbirliği yanlısı, 
sosyal ilişkilerde nazik, sevecen, esnek, dostane, rekâbet ve mücadele etmektense birlikte hareket etmeyi arzu eden tipleri tanımlamak için kullanılmaktadır. Sorumluluk; dürüstlük, güvenilirlik, dikkat, ısrarcılık, öz disiplin gösteren kişilerin sahip olduğu tiplerdir. Açıklık ise zeki, hayal gücü yüksek, sanata eğilimli, meraklı ve bilgili kimseler olarak tanımlanmaktadır. Beş faktör kuramına ait her bir özellik, kişinin tanınmasında geniş bakış açısı oluşturmanın yollarını sunmaktadır (Carver ve Connor-Smith, 2010).

\subsection{Duygusal Emek}

İşyerinde gerçekleştirilecek verimlilik çabalarına duyguları yönetme sürecinin de dâhil olmasıyla duygusal emek kavramı ortaya çıkmıştır. Kavram ile ilgili ilk detaylı çalışmayı yapan Hochschild (1983)'e göre duygular, yönetilmesi yoluyla ekonomik değere dönüşmekte, bu yönetim sırasında bir ücret karşılığında sergileniyorsa duygusal emek olmaktadır. Duygusal emek, çalışanların örgütsel olarak onaylanmış duyguları sergileme çabalarıdır (Wharton, 1999). Ayrıca duygusal emek, çalışanların duygularını kontrol etmesi, örgütlerin belirlediği olumlu duyguları gösterme çabalarıdır (Kaya ve Serçeoğlu, 2013: 316). Hochschild (1983) çalışanların, duyguları sergileme sürecinde istenilen davranışı örgütlerin taleplerine uygun fakat kendileri hissetmeyerek davranmalarını yüzeysel rol yapma, çalışanların müşterilerle ilişkilerinde duygularını kontrol ederek, olumlu duygular sergileme çabaları, örgütün istediği davranışı hissederek sergilemesini ise derinden rol yapma olarak ifade etmektedir (Hochschild, 1983; Gülaydın, 2019).

Ashforth ve Humpery (1993), Hochschild'in tanımladığı yüzeysel rol yapma ve derinden rol yapma duygusal emek boyutlarına samimi davranış olarak ifade ettiği üçüncü bir boyut eklemiştir. Samimi davranış, örgütün çalışanından beklediği olumlu duygu gösterimlerini herhangi bir zorlama olmadan, kendi içinden gelen duygularla rol yapmasına gerek kalmadan sergilemesidir. Grandey (2000) ise duygusal emeği, işlerin devamlılığı için gereken organizasyonlarca koyulan kuralların ışığında duygusal ifadeleri değiştirmek adına duyguları ön plana çıkarma, bastırma veya rol yapma davranışları olarak tanımlamaktadır. Bu duygusal tepkilerin oluşma süreci; beklentiler doğrultusunda duygu düzenlemelerine, yönetilmesine gereksinim duymaktadır. Yönetilen duygular derin davranış ve yüzeysel davranış olarak iki şekilde ortaya çıkmaktadır (Demirel, 2015; Grandey, 2000).

Otel işletmelerinde bireyin performansı, hem hizmetin sunumunu hem de kişiler arası davranışlar, duygusal ifadeler gibi maddi olmayan göstergeleri içermektedir. Hizmet sunumu sırasında gösterilen duygusal iş gücü stratejileri, performans, kârlılık gibi önemli organizasyonel sonuçları olumlu etkilerken (Goodwin ve diğ., 2011) kişinin refahını da olumsuz etkileyebilmektedir (Hochschild, 1983). Pozitif duygusal emek sergilemek için öfkenin gizlenmesi gerekmekte; bu durum kişinin psikolojik iyi olma haline zarar verebilmektedir (Erickson ve Ritter, 2001; Hochschild, 1983). Duygusal emek gösteren kişilerin tükenmişlik, daha az iş doyumu, daha fazla stres yaşadıklarını öne süren (Grandey, 2000; Wharton, 1999) çalışmalar mevcut olmakla birlikte yüksek iş doyumu, düşük stres ve psikolojik olarak daha dayanıklı olduklarını gösteren çalışmalar da mevcuttur (Biçkes ve diğ., 2014; Cheung ve Tang, 2010). Çalışanların bireysel farklılıklarının, özellikle de kişiliklerinin yine duygu gösterimleri üzerinde etkili olduğunu söylemek mümkündür (Barrick ve Mount, 2005; Beğenirbaş ve Yalçın, 2012; Tews ve Glomb, 2004). 


\subsection{Kişilik, duygusal emek ve yılmazlık arasındaki ilişkiler}

Son zamanlarda kişilik ve yılmazlık arasındaki ilişkilerin incelendiği çalışmalara literatürde yer verildiği görülmektedir (Eley ve diğ., 2013; Eley ve diğ., 2016; Kim ve diğ., 2013; Peng ve diğ., 2012). Kişilik özellikleri ya da yılmazlık kavramlarının örgütlerde incelenmesindeki amaç; liderler, çalışanlar ve örgütlerde var olan kapasitenin güçlü yanlarını ortaya çıkarabilmektir (Çavuşoğlu ve Yalçın, 2017). Otel işletmelerinin emek yoğun yapısı gereği iletişimin yoğun olması ve müşteri memnuniyetinin sağlanmasında çalışanların kurdukları bu iletişimin etkili olmasından dolayı özellikle çalışanların kişiliklerinin bilinmesi karar vericiler için yararlı olacaktır. Bu nedenle önem kazanan kişilik ile yılmazlık ilişkilerini inceleyen çalışmaların (CampbellSills ve diğ., 2006; Eley ve diğ., 2013; Eley ve diğ., 2016; Kim ve diğ., 2013; Peng ve diğ., 2012) hizmet sektörü içerisinde yer alan sağlık sektörü çalışanları veya tıp öğrencileri üzerinde yoğunlaştığı görülmektedir. Bu çalışmaların temelinde hangi kişilik özelliğinin bireyin yılmazlığını etkilediği yönündeki incelenmeler yatmaktadır. Örneğin, Nevrotik kişilerin olumsuz duyguları bastırdıkları ve bu kişilerin psikolojik iyi oluş halini olumsuz etkilediği incelenmiştir (Tews ve Glomb, 2004). Campbell-Sills ve diğ. (2006), yaptıkları çalışmada yılmazlık ile nevrotiklik arasında negatif ilişki belirlemiş, dışa dönüklük ve vicdanlılıkla pozitif olarak ilişki bulunmuştur. Liu ve diğ. (2012), nevrotikliğin, olumlu duyguları azaltarak yaşam doyumu üzerinde zararlı bir etkiye sahip olan risk faktörü olarak hareket ettiğini savunmuşlardır. Çetin ve diğ. (2015), dışadönüklük, özdisiplin, gelişime açıklık ve uyumluluk seviyeleri yüksek, nörotiklik seviyeleri düşük kişilerin psikolojik dayanıklılıklarının yüksek olduğunu ortaya koymuşlardır. Sorumluluk kişilik özelliğine sahip bireyler güvenilir, becerikli, empati kurabilen, çözüm odaklı yılmaz bireyler oldukları gibi daha sağlıklı ilişkiler kurabilmekte, stresle baş ederek sağlık ve refahını koruyabilmektedirler (Campbell- Sills ve diğ., 2006; Eley ve diğ., 2013). Friborg ve diğ. (2005), kişiliğin uyumluluk boyutunun yılmazlığın sosyal yeterlilik ve sosyal kaynaklar boyutlarıyla ilişkili olduğunu ortaya koymaktadır. Ayrıca, öz disiplin kişilik özelliğinin yapısal stil ile nevrotiklik kişilik özelliğinin kendilik algısı ile aile uyumu yılmazlık boyutunun ise uyumluluk ve nevrotiklik kişilik özelliği ile ilişkili olduğunu belirtmektedir. Bu durumda yılmazlık özelliğinin kişilik özelliklerinden bağımsız olamayacağı iddia edilmiştir.

Duygusal emek gösterimleri, bireysel farklılıklardan etkilenebilmektedir. Bu çalışmada ele alınan beş faktörlü kişilik özellikleri ile ilişkileri incelendiğinde, dışadönük kişiliğe sahip bir birey daha fazla pozitif duygular yaşayacağından yüzeysel rol yapma davranışında bulunmasına daha az intiyaç duyabilmektedir (Diefendorrf ve diğ., 2005). Kiffin-Petersen ve diğ. (2011), yaptıkları çalışmada, duygusal açıdan dengesiz çalışanların duygusal emeklerini yönetmek için yüzey oyunculuk kullanma olasılıklarının daha yüksek olduğunu tespit etmişlerdir. Yine başka bir çalışmada beş faktör kişilik boyutları duygusal emeğin derin davranış boyutunu etkilediği ortaya konulmuştur (Yeni ve Özler, 2016). Ayrıca duygusal emek, yılmazlık ile de ilişkilendirilmektedir. Cheung ve Tang (2010), yaptığı çalışmasında çalışanların doğal duygu gösterimlerinin yüksek iş tatminine yol açtığını, daha iyi psikolojik sağlık ve düşük psikolojik stres gibi çeşitli olumlu sonuçları olduğunu belirtmektedir. Ayrıca çalışanların yüzeysel davranış sergilemelerinin iyi iş performansı ve psikolojik sağlıkta kullanılabilecek bilişsel kaynaklarını tüketebileceği de bildirilmektedir. Biçces ve diğ. (2014), Doğal duygular ile yılmazlık arasında anlamlı ve pozitif yönlü ilişkiler bulunmuştur. Bütün bu etkileşimler kişinin pozitif duygular sergilemesi ile iyi oluş halini etkileyebileceği gibi olumsuz durumların üstesinden gelebilmesini de destekleyeceği ön görülmektedir. 


\section{Yöntem}

\subsection{Araştırmanın Amacı}

Literatür incelendiğinde birçok çalışmanın kişilik tipleri - duygusal emek (Diefendorrf ve diğ., 2005; Yeni ve Özler, 2016), kişilik tipleri - yılmazlık (Campbell-Sills ve diğ., 2006; Eley ve diğ., 2013; Eley ve diğ., 2016; Kim ve diğ., 2013; Peng ve diğ., 2012) ya da duygusal emek - yılmazlık (Biçkes ve diğ., 2014; Cheung ve Tang, 2010) arasında ilişkiler bulunduğu görülmektedir. Kişilik tipleri, yılmazlığı destekleyen içsel koruyucu bir faktörken aynı zamanda duygusal emek davranışının oluşmasında da etkili olabilmektedir. Ayrıca kişilik tipleri ile yılmazlık arasındaki ilişkiyi inceleyen araştırmaların (Campbell-Sills ve diğ., 2006; Eley ve diğ., 2013; Eley ve diğ., 2016; Kim ve diğ., 2013; Peng ve diğ., 2012) hizmet sektörü içerisinde yer alan sağlık sektörü çalışanları veya tıp öğrencileri üzerinde yoğunlaştığı görülmektedir. Kişilik tipleri ile yılmazlık ilişkileri otel çalışanları için incelenirken duygusal emeğin aracı rolü üstlendiği ön görülmektedir. Bu nedenle, otel işletmelerindeki müşteri ile çalışan etkileşiminin olumlu sonuçlanmasında çalışanların kişilik, duygu ve davranışlarının etkilerinin araştııılması yararlı olacaktır. Bu çalışmanın amacı, otel işletmelerinin çalışanlarının kişilik tipleri ile yılmazlık düzeyleri arasındaki ilişki ve bu ilişkide duygusal emeğin aracı rolünü incelemektir. Aracılık ilişkisi, dört aşamada test edilmektedir ve genellikle bu aşamalar a) X'in Y'ye direkt etkisini (c yolu), b) X'in M üzerindeki etkisi (a yolu), c) M'nin $Y$ üzerindeki etkisi (b yolu), d) Aracı değişken olan $M$ ile $X$ aynı anda modele koyulduğunda X'in Y'ye olan etkisi (c' yolu) ile ifade edilmektedir (Gürbüz, 2019) (Şekil 1). Bu araştırmanın modeli (Şekil 1) ve amacına uygun geliştirilen yirmi hipotez aşağıdaki gibi ifade edilmektedir:

Şekil 1: Aracılık Etki Araştırma Modeli (Gürbüz, 2019: 49)

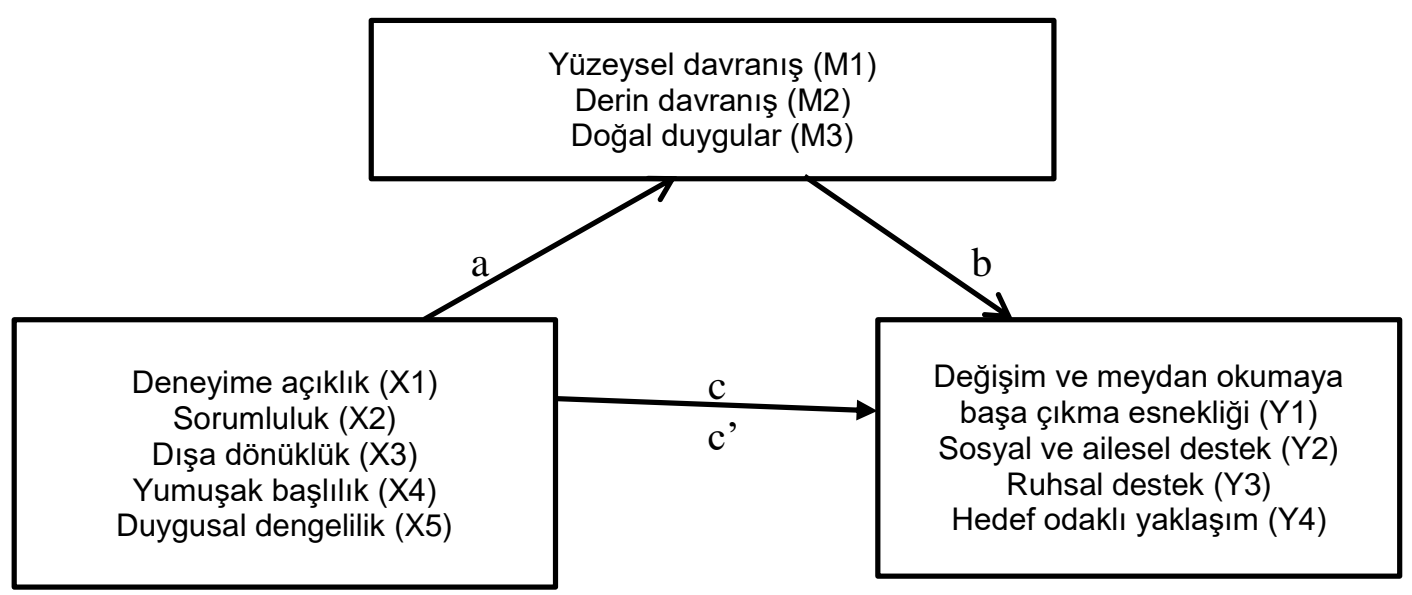

H1: "Deneyime açıklık" kişilik tipinin "değişim ve meydan okumayla başa çıkma esnekliği” yılmazlık özelliği üzerinde etkisinde duygusal emeğin aracı rolü vardır.

H2: "Deneyime açıklık" kişilik tipinin "sosyal ve ailesel destek" yılmazlık özelliği üzerinde etkisinde duygusal emeğin aracı rolü vardır.

H3: "Deneyime açıklık" kişilik tipinin "ruhsal destek" yılmazlık özelliği üzerinde etkisinde duygusal emeğin aracı rolü vardır. 
H4: "Deneyime açıklık" kişilik tipinin "hedef odaklı yaklaşım" yılmazlık özelliği üzerinde etkisinde duygusal emeğin aracı rolü vardır.

H5: "Sorumluluk" kişilik tipinin "değişim ve meydan okumayla başa çıkma esnekliği” yılmazlık özelliği üzerinde etkisinde duygusal emeğin aracı rolü vardır.

H6: "Sorumluluk" kişilik tipinin "sosyal ve ailesel destek" yılmazlık özelliği üzerinde etkisinde duygusal emeğin aracı rolü vardır.

H7: "Sorumluluk" kişilik tipinin "ruhsal destek" yılmazlık özelliği üzerinde etkisinde duygusal emeğin aracı rolü vardır.

H8: "Sorumluluk" kişilik tipinin "hedef odaklı yaklaşım" yılmazlık özelliği üzerinde etkisinde duygusal emeğin aracı rolü vardır.

H9: "Dışa dönüklük" kişilik tipinin "değişim ve meydan okumayla başa çıkma esnekliği” yılmazlık özelliği üzerinde etkisinde duygusal emeğin aracı rolü vardır.

H10: "Dışa dönüklük" kişilik tipinin "sosyal ve ailesel destek" yılmazlık özelliği üzerinde etkisinde duygusal emeğin aracı rolü vardır.

H11: "Dışa dönüklük" kişilik tipinin "ruhsal destek" yılmazlık özelliği üzerinde etkisinde duygusal emeğin aracı rolü vardır.

H12: "Dışa dönüklük" kişilik tipinin "hedef odaklı yaklaşım" yılmazlık özelliği üzerinde etkisinde duygusal emeğin aracı rolü vardır.

H13: "Yumuşak başılıı" kişilik tipinin "değişim ve meydan okumayla başa çıkma esnekliği” yılmazlık özelliği üzerinde etkisinde duygusal emeğin aracı rolü vardır.

H14: "Yumuşak başıılık" kişilik tipinin "sosyal ve ailesel destek" yılmazlık özelliği üzerinde etkisinde duygusal emeğin aracı rolü vardır.

H15: "Yumuşak başlılık" kişilik tipinin "ruhsal destek" yılmazlık özelliği üzerinde etkisinde duygusal emeğin aracı rolü vardır.

H16: "Yumuşak başlılık" kişilik tipinin "hedef odaklı yaklaşım" yılmazlık özelliği üzerinde etkisinde duygusal emeğin aracı rolü vardır.

H17: "Duygusal dengelilik" kişilik tipinin "değişim ve meydan okumayla başa çıkma esnekliği”" yılmazlık özelliği üzerinde etkisinde duygusal emeğin aracı rolü vardır.

H18: "Duygusal dengelilik" kişilik tipinin "sosyal ve ailesel destek" yılmazlık özelliği üzerinde etkisinde duygusal emeğin aracı rolü vardır.

H19: "Duygusal dengelilik" kişilik tipinin "ruhsal destek" yılmazlık özelliği üzerinde etkisinde duygusal emeğin aracı rolü vardır.

H20: "Duygusal dengelilik" kişilik tipinin "hedef odaklı yaklaşım" yılmazlık özelliği üzerinde etkisinde duygusal emeğin aracı rolü vardır. 


\subsection{Evren ve Örneklem}

Güçlü kurumsal yapılarından dolayı çalışmanın evrenini, İstanbul ilinde faaliyette bulunan beş yıldızlı otel işletmelerinin yöneticileri ile işgörenleri oluşturmaktadır. Kültür ve Turizm bakanlığının (2019) verilerine göre İstanbul'da, 131 adet 5 yıldızıı otel, 31 386 oda ve 62910 yatak kapasitesi ile faaliyet göstermektedir. Otel işletmelerinde yapılan bazı çalışmalara bakıldığında (Keleş, 2014; Demirel, 2015; 56; Gülaydın, 2019; 109) beş yıldızıı otel işletmelerinde odabaşına düşen ortalama çalışan sayısının 1.18 olarak kabul edilmesinden hareketle İstanbul'da faaliyet gösteren 5 yıldızlı otellerin çalışan sayısı (31 $386 \times 1.18) \mathrm{N}=37035$ olarak hesaplanmıştır. Burada faaliyet gösteren 5 yıldızlı otel sayısı ile bu otellerdeki çok sayıda insan kaynağı göz önünde bulundurulduğunda, tüm evrene ulaşmada maliyet, zaman gibi kısıtların meydana getirebileceği olumsuzluklardan dolayı çalışma, örneklem seçilerek yürütülmüştür. Evreni temsil etme gücünün yüksek olduğu seçkisiz örnekleme yöntemi (Yıldırım ve Şimşek, 2013) seçilmiş, bu yöntemin türlerinden ise basit seçkisiz örnekleme yöntemi kullanılarak çalışma gerçekleştirilmiştir. Çoğu işletme araştırması için evren büyüklüğü $\mathrm{N}>10000$ olduğundan örneklem geleneksel olarak kabul edilen \%95 güven düzeyi, bu seviye için t değeri 1.96 olup, standart sapma (S) 0.5 , sapma miktarı (d) 0.05 olarak

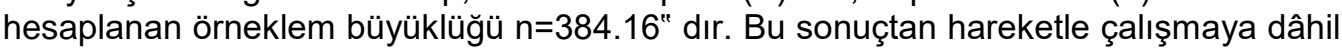
dilecek örneklem büyüklüğü en az 385 olmalıdır (Sekaran, 2003: 288). Bu yöntemin İstanbul' daki 5 yıldızlı otel çalışanlarının katılımcı olarak seçilmesine eşit seçilme şansı vermesinden dolayı (Sekaran, 2003: 257) gönüllülük gösteren 5 yıldızlı otellere uygulama için dağıtılan 500 anketten 443 adet anket formu geri dönmüş, eksik ve hatalı anketler çıkarılarak 434 anket değerlendirmeye alınmıştır.

\subsection{Veri Toplama Yöntemi}

Çalışma için kullanılan anket formu dört bölümden oluşmaktadır. Birinci bölümde, araştırmaya katılanların yaş, cinsiyet, medeni durum, eğitim durumu, işletmedeki pozisyonu gibi sosyo-demografik bilgilerini edinmeye yönelik sorular sorulmuştur. İkinci bölümde, kişilik tipleri ile ilgili veriler beş faktörlü model çerçevesinde oluşturulan, Gosling ve diğ. (2003) tarafından geliştirilmiş Atak (2013) tarafından Türkçeye uyarlanmış on maddeli Kişilik Ölçeği (OMKÖ) bulunmaktadır. Ölçeğe, açıklayıcı faktör analizi yapılmış, faktör yapısı incelendiğinde 5 faktörlü ve toplam varyansın \%72,507'sini açıklayabilen bir yapı görülmüştür (KMO: 0,793; madedelerin faktör yükleri dışa dönüklük 0,767-0,834, duygusal dengelilik 0,821-0,913, deneyime açıklık 0,703-0,935, sorumluluk 0,726-0,934, yumuşak başlılık 0,751-0,767 arasında değer almıştır). Ölçeğe ilişkin güvenilirlik analizi sonucunda Cronbach's Alpha katsayısı dışa dönüklük .72, duygusal dengelilik .68, deneyime açıklık .62, sorumluluk .66, yumuşak başlılık .70 olarak bulunmuştur.

Üçüncü bölümde ise çalışanların yılmazlık özellikleri ile ilgili veri toplamak amacıyla Connor ve Davidson (2003) tarafından geliştirilen 25 maddelik "Connor Davidson Resilience Scale" (CD-RISC) ölçeğinin, Dong ve diğ. (2013) tarafından orijinal ölçeğe iki madde daha eklenmesiyle yeniden düzenlenmiş dört boyutlu 27Maddeli Connor Davidson Yılmazlık Ölçeği (27-item CD-RISC) bulunmaktadır. Ölçeğe, açıklayıcı faktör analizi yapılmış, faktör yapısı incelendiğinde 4 faktörlü ve toplam varyansın \%64,3'ünü açıklayabilen bir yapı görülmüştür (KMO: 0,860; madedelerin faktör yükleri 0,611-0,730 arasında değer almıştır). Bu ölçekte güvenilirlik analizi sonucunda Cronbach's Alpha katsayısı bütün boyutlar için .89 olarak bulunmuştur. Son bölümde de Diefendorff ve diğ. (2005) tarafından geliştirilen ilk olarak Basım ve Beğenirbaş (2012) tarafından Türkçeye uyarlanmış, daha sonra Keleş (2014) tarafından yeniden uyarlanarak üç alt boyutta ve 14 maddeli Duygusal Emek Ölçeği 
(DEÖ) bulunmaktadır. Ölçeğe, açıklayıcı faktör analizi yapılmış, faktör yapısı incelendiğinde 3 faktörlü ve toplam varyansın \%56,915'ini açıklayabilen bir yapı görülmüştür (KMO: 0,764; madedelerin faktör yükleri 0,622-0,851 arasında değer almıştır). Güvenilirlik analizi sonucunda Cronbach's Alpha katsayısı yüzeysel rol yapma .78 , derinden rol yapma .78 , doğal duygular .80 olarak bulunmuştur.

\subsection{Verilerin Analizi}

Kişilik tiplerinin yılmazlık üzerinde etkisinde duygusal emeğin aracılık rolünün incelenmesinde bootstrap yöntemi kullanılarak regresyon analizi yapılmıştır. Bootstrap yönteminin Sobel testinden ve Baron ve Kenny'nin (1986) geleneksel yönteminden daha güvenilir sonuçlar verdiği yapılan araştırmalarda ortaya koyulmuştur (Hayes, 2018; Zhao ve diğ., 2010). Analizlerde bootstrap tekniği ile 5000 yeniden örnekleme tercih edilmiş, Hayes (2018) tarafından geliştirilen Process v3.3 makro uygulaması kullanılmıştır. Bootstrap ile çıkarımlarda bulunmak için kitlenin dağılımının bilinmesine veya kitle dağılımı ile ilgili herhangi bir varsayım yapılmasına gerek olmamaktadır. Bu örnekleme yöntemi varsayımların yetersiz kaldığı durumlarda güvenilir sonuçlar elde etmek için de kullanılmaktadır. Ayrıca bootstrap metodu, hipotezlerin test edilmesi, güven aralıkları ile regresyon analizinde de kullanılmaktadır (Takma ve Atıl, 2010). Bootstrap tekniği ile yapılan aracılık etkisi incelemelerinde, aracılık etkisinin olup olmadığı güven aralığına (confidence interval, $\mathrm{Cl}$ ) bakılarak anlaşımaktadır. Güven aralığı sıfır değerini kapsıyorsa aracılık etkisinin olmadığı ifade edilmektedir (MacKinnon ve diğ., 2004). Yapılan analizlerde standardize edilmemiş beta katsayıları (B) kullanılmış olup analizler \%95 güven aralığına göre yapılmıştır. Aracılık rolünün incelenmesine geçmeden önce araştırma değişkenlerinin normal dağılım sergileyip sergilemediği basıklık ve çarpıklık katsayısına bakılarak incelenmiştir (Tablo 1).

Tablo 1: Araştırma değişkenlerine ait tanımlayıcı istatistikler

\begin{tabular}{lccccl}
\hline & $\mathrm{n}$ & $\overline{\mathrm{x}}$ & $\mathrm{s}$ & Çarpıklık & Basıklık \\
\hline Kişilik Tipleri & & & & & \\
Dışa Dönüklük & 434 & 5.07 & 1.53 & -.44 & -.52 \\
Yumuşak Başlılık & 434 & 5.01 & 1.37 & -.21 & -.54 \\
Sorumluluk & 434 & 5.54 & 1.52 & -.98 & .33 \\
Duygusal Dengelilik & 434 & 4.74 & 1.51 & -.24 & -.66 \\
Deneyime Açıklık & 434 & 4.85 & 1.41 & -.41 & -.24 \\
\hline Yılmazlık & & & & & \\
Değişim ve Meydan Okumaya Başa & 434 & 3.83 & .61 & -.34 & -.23 \\
Çıkma Esnekliği & 434 & 3.88 & .65 & -.36 & -.45 \\
Sosyal ve Ailesel Destek & 434 & 3.83 & .72 & -.41 & -.21 \\
Ruhsal Destek & 434 & 3.83 & .61 & -.35 & -.26 \\
Hedef Odaklı Yaklaşım & & & & & \\
\hline Duygusal Emek & 434 & 2.95 & .89 & .07 & -.56 \\
Yüzeysel Davranış & 434 & 3.49 & .90 & -.25 & -.48 \\
Derin Davranış & 434 & 3.64 & .92 & -.32 & -.43 \\
Doğal Duygular & & & &
\end{tabular}

Tablo 1'de yer alan değerler incelendiğinde araştırma değişkenlerinin basıklık katsayılarının -0.66 ile 0.33 aralığında, çarpıklık katsayılarının ise -0.98 ile 0.07 aralığında olduğu görülmektedir. Bu değerler tüm değişkenlerin normal dağılım sergilediğini belirtmektedir (Karagöz, 2017: 124). Bu nedenle aracılık rolün incelenmesinde bootstrap yöntemi ile birlikte regresyon analizinin kullanılmasına devam edilmiştir. 


\section{Bulgular}

Tablo 2: Araştırma Katılımcılarına İlişkin Sosyo-demografik Özellikler

\begin{tabular}{|c|c|c|c|}
\hline & & $f$ & $\%$ \\
\hline \multirow{4}{*}{ Yaş } & 25 ve altı & 115 & 26.5 \\
\hline & $26-35$ & 191 & 44.0 \\
\hline & $36-45$ & 102 & 23.5 \\
\hline & 46 ve üzeri & 26 & 6.0 \\
\hline \multirow{2}{*}{ Cinsiyet } & Erkek & 272 & 62.7 \\
\hline & Kadın & 162 & 37.3 \\
\hline \multirow{3}{*}{ Medeni Durum } & Bekâr & 243 & 56.0 \\
\hline & Evli & 186 & 42.9 \\
\hline & Diğer & 5 & 1.2 \\
\hline \multirow{4}{*}{ Eğitim Durumu } & İlköğretim & 20 & 4.6 \\
\hline & Ortaöğretim & 181 & 41.7 \\
\hline & Lisans & 194 & 44.7 \\
\hline & Lisansüstü & 39 & 9.0 \\
\hline \multirow{2}{*}{ Pozisyon } & Yönetici & 98 & 22.6 \\
\hline & İşgören & 336 & 77.4 \\
\hline
\end{tabular}

Tablo 2'de sunulduğu gibi katılımcıların önemli bir bölümü (\%62.7) erkek, (\%44) 26-35 yaş aralığında, (\%44.7) lisans mezunu, (\%56) bekâr ve $(\% 77,4)$ çalışan bireylerden oluşmaktadır. Çalışmanın değişkenleri arasındaki ilişkilerin belirlenmesi için Pearson Çarpım Moment Korelasyon analizi uygulanmıştır (Tablo 3).

Tablo 3: Çalışmanın değişkenleri arasındaki korelasyon analizi sonuçları

\begin{tabular}{|c|c|c|c|c|c|c|c|c|c|c|c|c|}
\hline & K_dd & K_yb & K_so & K_dude & K_deac & Y_1dmobçe & Y_2sad & Y_3rd & Y_4hoy & DE_yry & DE_dry & DE_dd \\
\hline K_dd & 1 & & & & & & & & & & & \\
\hline K_yb & $.190^{* *}$ & 1 & & & & & & & & & & \\
\hline K_so & $.477^{* *}$ & $.387^{* *}$ & 1 & & & & & & & & & \\
\hline K_dude & $.205^{*}$ & $.352^{* *}$ & $.375^{* *}$ & 1 & & & & & & & & \\
\hline $\mathrm{K}$ deac & $.224^{* *}$ & .075 & $.327^{* *}$ & $.128^{* *}$ & 1 & & & & & & & \\
\hline $\begin{array}{l}\text { Y_1dm } \\
\text { obçe }\end{array}$ & $.273^{* *}$ & $.133^{* *}$ & $.241^{* *}$ & $.199^{* *}$ & $.260^{* *}$ & 1 & & & & & & \\
\hline Y_2sad & $.277^{* *}$ & $.132^{* *}$ & $.224^{* *}$ & $.119^{*}$ & $.259^{* *}$ & $.555^{+*}$ & 1 & & & & & \\
\hline Y_3rd & $.115^{*}$ & .066 & $.113^{*}$ & .062 & $.223^{* *}$ & $.491^{*}$ & $.462^{* *}$ & 1 & & & & \\
\hline$Y$ 4hoy & $.252^{* *}$ & $.135^{* *}$ & $.257^{* *}$ & $.201^{* *}$ & $.272^{* *}$ & $.745^{* *}$ & $.606^{* *}$ & $.482^{* *}$ & 1 & & & \\
\hline DE_yry & -.074 & -.077 & -.050 & -.041 & .021 & $.155^{* *}$ & $.105^{*}$ & .092 & $.212^{* *}$ & 1 & & \\
\hline DE_dry & .043 & .071 & .088 & .056 & $.141^{* *}$ & $.351^{* *}$ & $.333^{* *}$ & $.314^{* *}$ & $.386^{* *}$ & $.277^{* *}$ & 1 & \\
\hline DE_dd & .060 & $.207^{* *}$ & $.098^{*}$ & .045 & $.174^{* *}$ & $.275^{* *}$ & $.287^{* *}$ & $.220^{* *}$ & $.311^{* *}$ & -.046 & $.432^{* *}$ & 1 \\
\hline
\end{tabular}


Tablo 3 incelendiğinde çalışmanın bağımlı değişkeni olan yıımazlık boyutları ile kişilik boyutları ve duygusal emek boyutların arasında pozitif yönde anlamlı ilişkiler bulunduğu görülmektedir.

\subsection{Hipotez testleri}

İki değişken arasındaki ilişkinin üçüncü bir değişken aracılığıyla incelendiği analiz türüne aracı değişken analizi denilmektedir (Karagöz, 2017). Bağımsız değişkenin bağımlı değişken üzerindeki etkisini anlayabilmek için aracı değişkenlerden yardım alınabilmektedir. Aracı değişken analizinde; X bağımsız değişkeni (Kişilik tipleri: deneyime açıklık (X1), sorumluluk (X2), dışa dönüklük (X3), yumuşak başlılık (X4), duygusal dengelilik (X5), Y bağımlı değişkeni (Yılmazlık: değişim ve meydan okumaya başa çıkma esnekliği (Y1), sosyal ve ailesel destek (Y2), ruhsal destek (Y3), hedef odaklı yaklaşım (Y4)) ve M (Duygusal emek: Yüzeysel davranış (M1), Derin davranış (M2) ve Doğal duygular (M3)) aracı değişkeni temsil eder. Aracılık ilişkisi dört aşamada test edilmektedir ve genellikle bu aşamalar (Gürbüz, 2019); a) X'in Y'ye direkt etkisini (c yolu), b) X'in M üzerindeki etkisi (a yolu), c) M'nin Y üzerindeki etkisi (b yolu), d) Aracı değişken olan $\mathrm{M}$ ile $\mathrm{X}$ aynı anda modele koyulduğunda X'in Y'ye olan etkisi (c' yolu) ile ifade edilmektedir (Şekil 1).

Aracı değişken analizinde geleneksel yaklaşım ve çağdaş yaklaşım olmak üzere iki tür yaklaşımdan söz etmek mümkündür. Baron ve Kenny'nin nedensel adımlar yaklaşımı olarak da bilinen geleneksel yaklaşıma göre, aracı değişken etkisini analiz edebilmek için üç değişkenin teker teker yolları analiz edildiğinde dört adımının da koşulu karşılıyor olması gerekmektedir. Yani önerilen her bir koşul adım adım sağlanmalıdır (Gürbüz, 2019). Son yıllarda nedensel adımlar yaklaşımına getirilen eleştriler, aracılık modeli testlerinde daha geçerli ve güvenilir sonuçlar veren çağdaş yaklaşımın benimsenmesine katkıda bulunmuştur. Çağdaş yaklaşıma göre, Baron ve Kenny yönteminin birbiri ardına sıralanan dört adımla ilgili koşullar aranmamakta, bu koşullar gerçekleşmese bile aracılık etkisinin varlığından söz edilebilmektedir. Aracılık modelinin betimlenmesinde ise kısmi aracılık tam aracılık ifadeleri yerine doğrudan etki (c'), dolaylı etki (axb) ve toplam etki (c yolu) ifadelerini kullnamanın daha doğru olacağı belirtilmektedir. $\mathrm{Bu}$ yollar, standardize edilmemiş regresyon katsayılarından $(B)$ oluşmaktadır. Ayrıca Sobel testi yerine Boostrap metodu kullanılarak varsayımların karşılanamadığı durumlarda (axb yolu dağılımının normal olmaması gibi) bile daha güvenilir sonuçlar elde edilebilmektedir (Gürbüz, 2019; MacKinnon ve diğ., 2004).

\subsection{1 "Deneyime açıklık" kişilik tipinin yılmazlık üzerinde etkisinde duygusal emeğin aracı rolüne ait bulgular}

"Deneyime açıklık" kişilik tipinin sırasıyla yılmazlık alt boyutları üzerindeki etkisinde duygusal emek alt boyutlarının aracı rolü incelendiğinde; bu kişilk tipinin "değişim ve meydan okumaya başa çıkma esnekliği" üzerindeki toplam etkisi $(c=.00, p>.05)$, "sosyal ve ailesel destek" üzerindeki toplam etkisi (c=-.01, p>.05), "ruhsal destek" üzerindeki toplam etkisi (c=-.03, p>.05) ve "hedef odaklı yaklaşım" üzerindeki toplam etkisi ( $c=-.02, p>.05)$ anlamlı değildir (1.Aşama). Yine "Deneyime açıklık" kişilik tipinin aracı değişkenler olan Yüzeysel davranış $(B=.02, p>.05)$, Derin davranış (M2) $(B=.02$, $p>.05)$ ve Doğal duygular $(B=-.02, p>.05)$ üzerindeki doğrudan etkileri anlamlı değildir (2.Aşama) (Tablo 4).

Aracı değişkenlerin "değişim ve meydan okumaya başa çıkma esnekliği" üzerindeki doğrudan etkisi incelendiğinde ise, Yüzeysel davranışın $(B=.06, p>.05)$ anlamsız, Derin davranış $(B=.18, p<.05)$ ve Doğal duygular $(B=.11, p<.05)$ alt 
boyutlarının anlamlı etkisi olduğu görülmektedir. Aracı değişkenlerin "sosyal ve ailesel destek" üzerindeki doğrudan etkisi incelendiğinde, Yüzeysel davranış alt boyutunun $(B=.07, p>.05)$ anlamsız, Derin davranış $(B=.14, p<.05)$ ve Doğal duygular $(B=.11$, $p<.05)$ alt boyutlarının anlamlı etkisi olduğu görülmektedir. Aracı değişkenlerin "ruhsal destek" üzerindeki doğrudan etkisi incelendiğinde, Yüzeysel davranış $(B=.05, p>.05)$ ve Doğal duygular $(B=.11, p>.05)$ alt boyutlarının anlamsız, Derin davranış $(B=.25$, $p<.05)$ alt boyutunun anlamlı etkisi olduğu görülmektedir. Aracı değişkenlerin "hedef odaklı yaklaşım" üzerindeki doğrudan etkisi incelendiğinde, Yüzeysel davranış $(B=.07$, $\mathrm{p}<.05)$ Derin davranış $(B=.21, \mathrm{p}<.05)$ ve Doğal duygular $(B=.14, \mathrm{p}<.05)$ alt boyutlarının anlamlı etkisi olduğu görülmektedir (3.Aşama) (Tablo 4).

"Deneyime açıklık" ile tüm aracı değişkenler modele eş zamanlı olarak alındığında (4.Aşama) "deneyime açıklık" kişilik tipinin "değişim ve meydan okumaya başa çıkma esnekliği” üzerindeki doğrudan etkisi $\left(c^{\prime}=.00, p>.05\right)$ ve dolaylı etkisi (nokta tahmini=.003, \%95 Cl [-.01, .02]) anlamlı değildir. Bu sonuca göre duygusal emeğin aracı rolü olmadığı görülmektedir (H1: Kabul edilmemiştir). "Deneyime açıklık" kişilik tipinin "sosyal ve ailesel destek" üzerindeki doğrudan etkisi $(c$ '=-.02, $p>.05)$ ve dolaylı etkisi (nokta tahmini=.002, \%95 Cl [-.01, .02]) de anlamlı değildir. Bu sonuca göre duygusal emeğin aracı rolü olmadığı görülmektedir (H2: Kabul edilmemiştir). Aynı zamanda "deneyime açıklık" kişilik tipinin "ruhsal destek" üzerindeki doğrudan etkisi $\left(c^{\prime}=-.03, p>.05\right)$ ve dolaylı etkisi (nokta tahmini $=.004, \% 95 \mathrm{Cl}[-.01, .02]$ ) anlamlı değildir. Bu sonuca göre duygusal emeğin aracı rolü olmadığı görülmektedir (H3: Kabul edilmemiştir). "Deneyime açıklık" kişilik tipinin "hedef odaklı yaklaşım" üzerindeki doğrudan etkisi $\left(c^{\prime}=-.02, p>.05\right)$ ve dolaylı etkisi (nokta tahmini=-.003, \%95 Cl [-.01, .02]) anlamlı değildir. Bu sonuca göre duygusal emeğin aracı rolü olmadığı görülmektedir (H4: Kabul edilmemiştir) (Tablo 4).

Tablo 4: Aracılık analizi sonuçları

\begin{tabular}{|c|c|c|c|c|c|c|}
\hline & $\begin{array}{l}\text { a yolu } \\
(\mathrm{X} \rightarrow \mathrm{M})\end{array}$ & $\begin{array}{l}\text { b yolu } \\
(\mathbf{M} \rightarrow \mathbf{Y})\end{array}$ & $\begin{array}{l}\text { c yolu } \\
(X \rightarrow Y)\end{array}$ & $\begin{array}{l}\text { c' yolu } \\
\text { Doğrudan etki }\end{array}$ & $\begin{array}{l}\text { Nokta tahmini } \\
\text { (nt), CI }\end{array}$ & $\begin{array}{l}\text { Kabul } \\
\text { /Red }\end{array}$ \\
\hline $\begin{array}{l}\mathrm{H1}_{\left(\mathrm{X}_{1} \rightarrow \mathrm{M}_{1}, \mathrm{M}_{2},\right.} \\
\left.\mathrm{M}_{3} \rightarrow \mathrm{Y}_{1}\right)\end{array}$ & $\begin{array}{l}B=.02, \mathrm{p}>.05 \\
B=.02, \mathrm{p}>.05 \\
B=.02, \mathrm{p}>.05\end{array}$ & $\begin{array}{l}B=.06, \mathrm{p}>.05 \\
B=. \mathbf{1 8}, \mathbf{p}<. \mathbf{0 5} \\
B=. \mathbf{1 1}, \mathbf{p}<. \mathbf{0 5}\end{array}$ & $\mathrm{c}=.00, \mathrm{p}>.05$ & $c^{\prime}=.00, p>.05$ & $\begin{array}{l}\mathrm{nt}=.003, \% 95 \\
\mathrm{Cl}[-.01, .02]\end{array}$ & Red \\
\hline 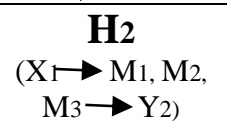 & $\begin{array}{l}B=.02, \mathrm{p}>.05 \\
B=.02, \mathrm{p}>.05 \\
B=-.02, \mathrm{p}>.05\end{array}$ & $\begin{array}{l}B=.07, \mathrm{p}>.05 \\
B=. \mathbf{1 4}, \mathbf{p}<. \mathbf{0 5} \\
B=\mathbf{. 1 1}, \mathbf{p}<.05\end{array}$ & $\mathrm{c}=-.01, \mathrm{p}>.05$ & $\mathrm{c}^{\prime}=-.02, \mathrm{p}>.05$ & $\begin{array}{l}\mathrm{nt}=.002, \% 95 \\
\mathrm{Cl}[-.01, .02]\end{array}$ & Red \\
\hline 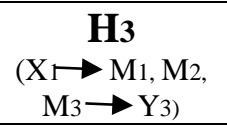 & $\begin{array}{l}B=.02, \mathrm{p}>.05 \\
B=.02, \mathrm{p}>.05 \\
B=-.02, \mathrm{p}>.05\end{array}$ & $\begin{array}{l}B=.05, \mathrm{p}>.05 \\
B=.11, \mathrm{p}>.05 \\
B=.25, \mathbf{p}<.05\end{array}$ & $c=-.03, p>.05$ & $c^{\prime}=-.03, p>.05$ & $\begin{array}{l}\mathrm{nt}=.004, \% 95 \\
\mathrm{Cl}[-.01, .02]\end{array}$ & Red \\
\hline$\underset{\left.\substack{\mathrm{X}_{\mathrm{M}} \rightarrow \mathrm{M}_{1}, \mathrm{M}_{2}, \rightarrow} 4\right)}{\left.\mathrm{Y}_{4}\right)}$ & $\begin{array}{l}B=.02, \mathrm{p}>.05 \\
B=.02, \mathrm{p}>.05 \\
B=-.02, \mathrm{p}>.05\end{array}$ & $\begin{array}{l}B=.07, \mathrm{p}<.05 \\
B=.21, \mathrm{p}<.05 \\
B=.14, \mathrm{p}<.05\end{array}$ & $\mathrm{c}=-.02, \mathrm{p}>.05$ & $\mathrm{c}^{\prime}=-.02, \mathrm{p}>.05$ & $\begin{array}{l}\mathrm{nt}=-.003, \% 95 \\
\mathrm{Cl}[-.01, .02]\end{array}$ & Red \\
\hline
\end{tabular}

Bağımsız Değişkenler: Deneyime açıklık (X1)

Bağımlı değişkenler: Değişim ve meydan okumaya başa çıkma esnekliği (Y1), Sosyal ve ailesel destek (Y2), Ruhsal destek (Y3), Hedef odaklı yaklaşım (Y4)

Aracı Değişkenler: Yüzeysel davranış (M1), Derin davranış (M2) ve Doğal duygular (M3) 


\subsection{2 "Sorumluluk" kişilik tipinin yılmazlık üzerinde etkisinde duygusal emeğin aracı rolüne ait bulgular}

"Sorumluluk" kişilik tipinin sırasıyla yılmazlık alt boyutları üzerindeki etkisinde duygusal emek alt boyutlarının aracı rolü incelendiğinde; bu kişilik tipinin "değişim ve meydan okumaya başa çıkma esnekliği" üzerindeki toplam etkisi $(c=.03, p>.05)$, "sosyal ve ailesel destek" üzerindeki toplam etkisi (c=.03, p>.05), "ruhsal destek" üzerindeki toplam etkisi ( $c=.02, p>.05)$ ve "hedef odaklı yaklaşım" üzerindeki toplam etkisi ( $c=.00$, p>.05) anlamlı değildir (1.Aşama). Yine "Sorumluluk" kişilik tipinin aracı değişkenler olan Yüzeysel davranış $(B=.02, p>.05)$, Derin davranış $(B=.02, p>.05)$ ve Doğal duygular ( $B=-.01, p>.05)$ üzerindeki doğrudan etkileri anlamlı değildir (2.Aşama) (Tablo 5).

Aracı değişkenlerin "değişim ve meydan okumaya başa çıkma esnekliği" üzerindeki doğrudan etkisi incelendiğinde, Yüzeysel davranışın $(B=.06, p>.05)$ anlamsız, Derin davranış $(B=.18, p<.05)$ ve Doğal duygular $(B=.11, p<.05)$ alt boyutlarının anlamlı etkisi olduğu görülmektedir. Aracı değişkenlerin "sosyal ve ailesel destek" üzerindeki doğrudan etkisi incelendiğinde, Yüzeysel davranışın ( $B=.07, p>.05)$ anlamsız, Derin davranış $(B=.14, p<.05)$ ve Doğal duygular $(B=.11, p<.05)$ alt boyutlarının anlamlı etkisi olduğu görülmektedir. Aracı değişkenlerin "ruhsal destek" üzerindeki doğrudan etkisi incelendiğinde, Yüzeysel davranış $(B=.05, p>.05)$ ve Doğal duygular $(B=.11, \mathrm{p}>.05)$ alt boyutunun anlamsız, Derin davranış $(B=.25, \mathrm{p}<.05)$ alt boyutunun anlamlı etkisi olduğu görülmektedir. Aracı değişkenlerin "hedef odaklı yaklaşım" üzerindeki doğrudan etkisi incelendiğinde, Yüzeysel davranış $(B=.07, p<.05)$, Derin davranış $(B=.21, \mathrm{p}<.05)$ ve Doğal duygular $(B=.14, \mathrm{p}<.05)$ alt boyutlarının anlamlı etkisi olduğu görülmektedir (3.Aşama) (Tablo 5).

"Sorumluluk" ile tüm aracı değişkenler modele eş zamanlı olarak alındığında (4.Aşama) "sorumluluk" kişilik tipinin "değişim ve meydan okumaya başa çıkma esnekliği" üzerindeki doğrudan etkisi $(c$ '=.02, $p>.05)$ ve dolaylı etkisi (nokta tahmini=.004, \%95 Cl [-.01, .02]) anlamlı değildir. Bu sonuca göre duygusal emeğin aracı rolü olmadığı görülmektedir (H5: Kabul edilmemiştir). "Sorumluluk" kişilik tipinin "sosyal ve ailesel destek" üzerindeki doğrudan etkisi $(c$ ' $=.03, p>.05)$ ve dolaylı etkisi (nokta tahmini=.003, \%95 $\mathrm{Cl}[-.01, .02]$ ) de anlamlı değildir. Bu sonuca göre duygusal emeğin aracı rolü olmadığı görülmektedir (H6: Kabul edilmemiştir). Ayrıca, "sorumluluk" kişilik tipinin "ruhsal destek" üzerindeki doğrudan etkisi $(c$ '=.02, $p>.05)$ ve dolaylı etkisi (nokta tahmini=.006, \%95 Cl [-.01, .03]) anlamlı değildir. Bu sonuca göre duygusal emeğin aracı rolü olmadığı görülmektedir (H7: Kabul edilmemiştir). "Sorumluluk" kişilik tipinin "hedef odaklı yaklaşım" üzerindeki doğrudan etkisi $(c$ ' $=.00$, $p>.05)$ ve dolaylı etkisi nokta tahmini $=.005, \% 95 \mathrm{Cl}[-.01, .03])$ de anlamlı değildir $\mathrm{Bu}$ sonuca göre duygusal emeğin aracı rolü olmadığı görülmektedir (H8: Kabul edilmemiştir) (Tablo 5). 
Tablo 5: Aracılık analizi sonuçları

\begin{tabular}{|c|c|c|c|c|c|c|}
\hline & $\begin{array}{l}\text { a yolu } \\
(X \rightarrow M)\end{array}$ & $\begin{array}{l}\text { b yolu } \\
(M \rightarrow Y)\end{array}$ & $\begin{array}{l}\text { c yolu } \\
(X \rightarrow Y)\end{array}$ & $\begin{array}{l}\text { c' yolu } \\
\text { Doğrudan etki }\end{array}$ & $\begin{array}{ll}\text { Nokta } & \text { tahmini } \\
\text { (nt), Cl }\end{array}$ & $\begin{array}{l}\text { Kabul } \\
\text { /Red }\end{array}$ \\
\hline $\begin{array}{c}\text { H5 } \\
(\mathrm{X} 2 \rightarrow \mathrm{M} 1, \mathrm{M} 2, \\
\mathrm{M} 3 \rightarrow \mathrm{Y} 1)\end{array}$ & $\begin{array}{l}B=.02, p>.05 \\
B=.02, p>.05 \\
B=-.01, p>.05\end{array}$ & $\begin{array}{l}B=-.01, p>.05 \\
B=.18, p<.05 \\
B=.11, p<.05\end{array}$ & $\mathrm{c}=.03, \mathrm{p}>.05$ & $c^{\prime}=.02, p>.05$ & $\begin{array}{l}\mathrm{nt}=.004, \% 95 \mathrm{Cl} \\
{[-.01, .02]}\end{array}$ & Red \\
\hline $\begin{array}{l}(\mathrm{X} 2 \rightarrow \mathrm{M} \text { 1, M2, } \\
\mathrm{M} 3 \rightarrow \mathrm{Y} 2)\end{array}$ & $\begin{array}{l}B=.02, \mathrm{p}>.05 \\
B=.02, \mathrm{p}>.05 \\
B=-.01, \mathrm{p}>.05\end{array}$ & $\begin{array}{l}B=.07, p>.05 \\
B=.14, p<.05 \\
B=.11, p<.05\end{array}$ & $\begin{array}{l}\mathrm{C}=.03 \\
>.05\end{array}$ & $c^{\prime}=.03, p>.05$ & $\begin{array}{l}\mathrm{nt}=.003, \% 95 \mathrm{Cl} \\
{[-.01, .02]}\end{array}$ & Red \\
\hline $\begin{array}{c}\mathrm{H7} \\
(\mathrm{X} 2 \rightarrow \mathrm{M} 1, \mathrm{M} 2,\end{array}$ & $\begin{array}{l}B=.02, p>.05 \\
B=.02, p>.05 \\
B=-.01, p>.05\end{array}$ & $\begin{array}{l}B=.05, p>.05 \\
B=.11, p>.05 \\
B=.25, p<.05\end{array}$ & $\mathrm{c}=.02, \mathrm{p}>.05$ & $c^{\prime}=.02, p>.05$ & $\begin{array}{l}\mathrm{nt}=.006, \% 95 \mathrm{Cl} \\
{[-.01, .03]}\end{array}$ & Red \\
\hline $\begin{array}{l}\mathrm{H8} \\
\mathrm{M} 3 \rightarrow \mathrm{M} 1, \mathrm{M} 2,\end{array}$ & $\begin{array}{l}B=.02, p>.05 \\
B=.02, p>.05 \\
B=-.01, p>.05\end{array}$ & $\begin{array}{l}B=.07, p<.05 \\
B=.21, p<.05 \\
B=.14, p<.05\end{array}$ & $\mathrm{C}=.00, \mathrm{p}>.05$ & $c^{\prime}=.00, p>.05$ & $\begin{array}{l}\mathrm{nt}=.005, \% 95 \mathrm{Cl} \\
{[-.01, .03]}\end{array}$ & Red \\
\hline
\end{tabular}

Bağımsız Değişkenler: Sorumluluk (X2),

Bağımlı değişkenler: Değişim ve meydan okumaya başa çıkma esnekliği (Y1), Sosyal ve ailesel destek (Y2), Ruhsal destek (Y3), Hedef odaklı yaklaşım (Y4)

Aracı Değişkenler: Yüzeysel davranış (M1), Derin davranış (M2) ve Doğal duygular (M3)

\subsection{3 “Dışa dönüklük" kişilik tipinin yılmazlık üzerinde etkisinde duygusal emeğin aracı rolüne ait bulgular}

"Dışa dönüklük" kişilik tipinin sırasıyla yılmazlık alt boyutları üzerindeki etkisinde duygusal emek alt boyutlarının aracı rolü incelendiğinde; bu kişilik tipinin "değişim ve meydan okumaya başa çıkma esnekliği" üzerindeki toplam etkisi $(c=.04, p>.05)$ ile "hedef odaklı yaklaşım" üzerindeki toplam etkisi $(c=.02, p>.05)$ anlamlı değildir. Diğer yandan "dışa dönüklük" kişilik tipinin "sosyal ve ailesel" üzerindeki toplam etkisi (c=.09, $p<.05)$ ile "ruhsal destek" üzerindeki toplam etkisi $(c=.15, p<.05)$ anlamlıdır (1.Aşama). "Dışa dönüklük" kişilik tipinin aracı değişkenler olan Yüzeysel davranış $(B=.06, p>.05)$ üzerindeki doğrudan etkisi anlamsız, Derin davranış $(B=.10, p<.05)$ ve Doğal duygular $(B=.10, p<.05)$ üzerindeki doğrudan etkisi anlamlıdır (2.Aşama) (Tablo 6).

Aracı değişkenlerin "değişim ve meydan okumaya başa çıkma esnekliği" üzerindeki doğrudan etkisi incelendiğinde, Yüzeysel davranışın $(B=.06, p>.05)$ anlamsız, Derin davranış $(B=.18, p<.05)$ ve Doğal duygular $(B=.11, p<.05)$ alt boyutlarının anlamlı etkisi olduğu görülmektedir. Aracı değişkenlerin "sosyal ve ailesel destek" üzerindeki doğrudan etkisi incelendiğinde, Yüzeysel davranışın ( $B=.07, \mathrm{p}>.05)$ anlamsız, Derin davranış $(B=.14, p<.05)$ ve Doğal duygular $(B=.11, p<.05)$ alt boyutlarının anlamlı etkisi olduğu görülmektedir. Aracı değişkenlerin "ruhsal destek" üzerindeki doğrudan etkisi incelendiğinde, Yüzeysel davranış $(B=.05, p>.05)$ ve Doğal duygular $(B=.11, \mathrm{p}>.05)$ alt boyutlarının anlamsız, Derin davranış $(B=.25, \mathrm{p}<.05)$ alt boyutlarının anlamlı etkisi olduğu görülmektedir. Aracı değişkenlerin "hedef odaklı yaklaşım" üzerindeki doğrudan etkisi incelendiğinde, Yüzeysel davranış ( $B=.07, p<.05)$, Derin davranış $(B=.21, \mathrm{p}<.05)$ ve Doğal duygular $(B=.14, \mathrm{p}<.05)$ alt boyutlarının anlamlı etkisi olduğu görülmektedir (3.Aşama) (Tablo 6).

"Dışa dönüklük" ile tüm aracı değişkenler modele eş zamanlı olarak alındığında (4.Aşama) "dışa dönüklük" kişilik tipinin "değişim ve meydan okumaya başa çıkma esnekliği" üzerindeki doğrudan etkisi anlamlı değildir ( $\left.c^{\prime}=.01, p>.05\right)$. Bu sonuca göre duygusal emeğin aracı rolü olmadığı görülmektedir. Aynı zamanda "dışa dönüklük" 
kişilik tipinin "değişim ve meydan okumaya başa çıkma esnekliği" üzerindeki dolaylı etkisi anlamlı olmasına rağmen (nokta tahmini=.032, \%95 Cl [.01, .05]) diğer şartlar sağlamadığı için aracı etki görülmemektedir (H9: Kabul edilmemiştir). Diğer yandan "dışa dönüklük" kişilik tipinin "sosyal ve ailsel destek" üzerindeki doğrudan etkisi $\left(c^{\prime}=.06, p<.05\right)$ ve dolaylı etkisi (nokta tahmini=.027, \%95 Cl $[.01, .05]$ ) anlamlıdır. Bu nedenle "dışa dönüklük" kişilik tipinin "sosyal ve ailesel destek" üzerindeki etkisinde "derin davranış" ve doğal duygular" alt boyutlarının aracı etkisi olduğu görülmektedir (H10: Kabul edilmiştir). Aynı zamanda "dışa dönüklük" kişilik tipinin "ruhsal destek" üzerindeki doğrudan etkisi $\left(c^{\prime}=.11, p<.05\right)$ ve dolaylı etkisi (nokta tahmini=.035, \%95 Cl $[.01, .06])$ anlamlıdır. Bu nedenle "dışa dönüklük" kişilik tipinin "ruhsal destek" üzerindeki etkisinde "derin davranış" alt boyutunun aracı etkisi olduğu görülmektedir (H11: Kabul edilmiştir). "Dışa dönüklük" kişilik tipinin "hedef odaklı yaklaşım" üzerindeki doğrudan etkisi anlamlı değildir ( $\left.c^{\prime}=-.02, p>.05\right)$. Bu sonuca göre duygusal emeğin aracı rolü olmadığı görülmektedir. Aynı zamanda "dışa dönüklük" kişilik tipinin "hedef odaklı yaklaşım" üzerindeki dolaylı etkisi anlamlı olmasına rağmen (nokta tahmini=.039, \%95 Cl $[.02$, .07]) diğer şartlar sağlamadığı için aracı etki görülmemektedir (H12: Kabul edilmemiştir) (Tablo 6).

Tablo 6: Aracılık analizi sonuçları

\begin{tabular}{|c|c|c|c|c|c|c|}
\hline & $\begin{array}{l}\text { a yolu } \\
(X \rightarrow M)\end{array}$ & $\begin{array}{l}\text { b yolu } \\
(M \rightarrow Y)\end{array}$ & $\begin{array}{l}\text { c yolu } \\
(X \rightarrow Y)\end{array}$ & $\begin{array}{l}\text { c' yolu } \\
\text { Doğrudan etki }\end{array}$ & $\begin{array}{ll}\text { Nokta } & \text { tahmini } \\
\text { (nt), Cl }\end{array}$ & $\begin{array}{l}\text { Kabul } \\
\text { /Red }\end{array}$ \\
\hline $\begin{array}{c}\mathrm{H9} \\
(\mathrm{X} 3 \rightarrow \mathrm{M} 1, \mathrm{M} 2, \\
\mathrm{M} 3 \rightarrow \mathrm{Y} 1)\end{array}$ & $\begin{array}{l}B=.06, p>.05 \\
B=.10, p<.05 \\
B=.10, p<.05\end{array}$ & $\begin{array}{l}B=.06, p>.05 \\
B=. \mathbf{1 8}, \mathrm{p}<.05 \\
B=. \mathbf{1 1}, \mathrm{p}<. \mathbf{0 5}\end{array}$ & $c=.04, p>.05$ & $c^{\prime}=.01, p>.05$ & $\begin{array}{l}\mathrm{nt}=.032, \% 95 \mathrm{Cl} \\
{[.01, .05]}\end{array}$ & Red \\
\hline $\begin{array}{c}(\mathrm{X} 3 \rightarrow \mathrm{M} 1, \mathrm{M} 2, \\
\mathrm{M} 3 \rightarrow \mathrm{Y} 2)\end{array}$ & $\begin{array}{l}B=.06, p>.05 \\
B=.10, p<.05 \\
B=.10, p<.05\end{array}$ & $\begin{array}{l}B=.07, p>.05 \\
B=.14, p<.05 \\
B=.11, p<.05\end{array}$ & $c=.09, p<.05$ & $c^{\prime}=.06, p<.05$ & $\begin{array}{l}\mathrm{nt}=.027, \% 95 \mathrm{Cl} \\
{[.01, .05]}\end{array}$ & Kabul \\
\hline $\begin{array}{c}(\mathrm{X} 3 \rightarrow \mathrm{M} 1, \mathrm{M} 2, \\
\mathrm{M} 3 \rightarrow \mathrm{Y} 3)\end{array}$ & $\begin{array}{l}B=.06, p>.05 \\
B=.10, p<.05 \\
B=.10, p<.05\end{array}$ & $\begin{array}{l}B=.05, p>.05 \\
B=.25, p<.05 \\
B=.11, p>.05\end{array}$ & $c=.15, p<.05$ & $c^{\prime}=.11, p<.05$ & $\begin{array}{l}\mathrm{nt}=.035, \% 95 \mathrm{Cl} \\
{[.01, .06]}\end{array}$ & Kabul \\
\hline $\begin{array}{c}(\mathrm{X} 3 \rightarrow \mathrm{M} 1, \mathrm{M} 2, \\
\mathrm{M} 3 \rightarrow \mathrm{Y} 4)\end{array}$ & $\begin{array}{l}B=.06, p>.05 \\
B=.10, p<.05 \\
B=.10, p<.05\end{array}$ & $\begin{array}{l}B=.07, p<.05 \\
B=.21, p<.05 \\
B=.14, p<.05\end{array}$ & $\mathrm{c}=.02, \mathrm{p}>.05$ & $c^{\prime}=-.02, p>.05$ & $\begin{array}{l}\mathrm{nt}=.039, \% 95 \mathrm{Cl} \\
{[.02, .07]}\end{array}$ & Red \\
\hline
\end{tabular}

Bağımsız Değişkenler: Dışa dönüklük (X3)

Bağımlı değiş̧kenler: Değişim ve meydan okumaya başa çıkma esnekliği (Y1), Sosyal ve ailesel destek (Y2), Ruhsal destek (Y3), Hedef odaklı yaklaşım (Y4)

Aracı Değişkenler: Yüzeysel davranış (M1), Derin davranış (M2) ve Doğal duygular (M3)

\subsection{4 "Yumuşak başlılık" kişilik tipinin yılmazlık üzerinde etkisinde duygusal emeğin aracı rolüne ait bulgular}

"Yumuşak başlılık" kişilik tipinin sırasıyla yılmazlık alt boyutları üzerindeki etkisinde duygusal emek alt boyutlarının aracı rolü incelendiğinde; bu kişilik tipinin "değişim ve meydan okumaya başa çıkma esnekliği" üzerindeki toplam etkisi $(c=.11, p<.05)$, "sosyal ve ailesel destek" üzerindeki toplam etkisi $(c=.14, p<.05)$, "ruhsal destek" üzerindeki toplam etkisi $(c=.09, p<.05)$ ve "hedef odaklı yaklaşım" üzerindeki toplam etkisi $(c=.07, p<.05)$ anlamlıdır (1.Aşama). "Yumuşak başlılık" kişilik tipinin aracı değişkenler olan Yüzeysel davranış $(B=-.02 p>.05)$, Derin davranış $(B=.03, p>.05)$ ve Doğal duygular $(B=.00, p>.05)$ üzerindeki doğrudan etkileri anlamlı değildir (2.Aşama) (Tablo 7). 
Aracı değişkenlerin "değişim ve meydan okumaya başa çıkma esnekliği” üzerindeki doğrudan etkisi incelendiğinde, Yüzeysel davranışın $(B=.06, p>.05)$ anlamsız, Derin davranış $(B=.18, p<.05)$ ve Doğal duygular $(B=.11, p<.05)$ alt boyutlarının anlamlı etkisi olduğu görülmektedir. Aracı değişkenlerin "sosyal ve ailesel destek" üzerindeki doğrudan etkisi incelendiğinde, Yüzeysel davranışın $(B=.07, p>.05)$ anlamsız, Derin davranış $(B=.14, \mathrm{p}<.05)$ ve Doğal duygular $(B=.11, \mathrm{p}<.05)$ alt boyutlarının anlamlı etkisi olduğu görülmektedir. Aracı değişkenlerin "ruhsal destek" üzerindeki doğrudan etkisi incelendiğinde, Yüzeysel davranış $(B=.05, \mathrm{p}>.05)$ ve Doğal duygular $(B=.11, \mathrm{p}>.05)$ alt boyutlarının anlamsız, Derin davranış $(B=.25, p<.05)$ alt boyutlarının anlamlı etkisi olduğu görülmektedir. Aracı değişkenlerin "hedef odaklı yaklaşım" üzerindeki doğrudan etkisi incelendiğinde, Yüzeysel davranış $(B=.07, \mathrm{p}<.05)$, Derin davranış $(B=.21, \mathrm{p}<.05)$ ve Doğal duygular $(B=.14, p<.05)$ alt boyutlarının anlamlı etkisi olduğu görülmektedir (3.Aşama) (Tablo 7).

"Yumuşak başlılık" ile tüm aracı değişkenler modele eş zamanlı olarak alındığında (4.Aşama), "yumuşak başlılık" kişilik tipinin "değişim ve meydan okumaya başa çıkma esnekliği” üzerindeki doğrudan etkisi anlamlı $(c$ ' $=.10, p<.05)$ ancak dolaylı etkisi anlamlı olmadığı (nokta tahmini=.004, \%95 Cl $[-.01, .02]$ ) için aracı etki görülmemektedir (H13: Kabul edilmemiştir). Ayrıca "yumuşak başlılık" kişilik tipinin "sosyal ve ailesel destek" üzerindeki doğrudan etkisi anlamlı $(c$ '=.13, $p<.05)$ ancak dolaylı etkisi anlamlı olmadığı (nokta tahmini=.002, \%95 Cl $[-.01, .02]$ ) için aracı etki görülmemektedir (H14: Kabul edilmemiştir). "Yumuşak başlılık" kişilik tipinin "ruhsal destek" üzerindeki doğrudan etkisi anlamlı ( $c$ '=.09, p<.05) ancak dolaylı etkisi anlamlı olmadığı (nokta tahmini=.006, \%95 Cl [-.02, .03]) için aracı etki görülmemektedir (H15: Kabul edilmemiştir). "Yumuşak başııık" kişilik tipinin "hedef odaklı yaklaşım" üzerindeki doğrudan etkisi anlamlı $\left(c^{\prime}=.06, p<.05\right)$ ancak dolaylı etkisi anlamlı olmadığı (nokta tahmini $=.004, \% 95 \mathrm{Cl}[-.02, .02])$ için aracı etki görülmemektedir (H16: Kabul edilmemiştir) (Tablo 7).

Tablo 7: Aracılık analizi sonuçları

\begin{tabular}{|c|c|c|c|c|c|c|}
\hline & $\begin{array}{l}\text { a yolu } \\
(X \rightarrow M)\end{array}$ & $\begin{array}{l}\text { b yolu } \\
(M \rightarrow Y)\end{array}$ & $\begin{array}{l}\text { c yolu } \\
(X \rightarrow Y)\end{array}$ & $\begin{array}{l}\text { C' yolu } \\
\text { Doğrudan etki }\end{array}$ & $\begin{array}{l}\text { Nokta } \text { tahmini } \\
\text { (nt), Cl }\end{array}$ & $\begin{array}{l}\text { Kabul } \\
\text { /Red }\end{array}$ \\
\hline $\begin{array}{c}\text { H13 } \\
(\mathrm{X} 4 \rightarrow \mathrm{M} 1, \mathrm{M} 2, \\
\mathrm{M} 3 \rightarrow \mathrm{Y} 1)\end{array}$ & $\begin{array}{l}B=-.02 \mathrm{p}>.05 \\
B=.03, \mathrm{p}>.05 \\
B=.00, \mathrm{p}>.05\end{array}$ & $\begin{array}{l}B=.06, p>.05 \\
B=.18, p<.05 \\
B=.11, p<.05\end{array}$ & $\mathrm{C}=.11, \mathrm{p}<.05$ & $c^{\prime}=.10, p<.05$ & $\begin{array}{l}\mathrm{nt}=.004, \% 95 \mathrm{Cl} \\
{[-.01, .02]}\end{array}$ & Red \\
\hline $\begin{array}{c}\mathrm{H14} \\
(\mathrm{X} 4 \rightarrow \mathrm{M} 1, \mathrm{M} 2, \\
\mathrm{M} 3 \mathrm{Y} 2)\end{array}$ & $\begin{array}{l}B=-.02 \mathrm{p}>.05 \\
B=.03, \mathrm{p}>.05 \\
B=.00, \mathrm{p}>.05\end{array}$ & $\begin{array}{l}B=.07, p>.05 \\
B=.14, p<.05 \\
B=.11, p<.05\end{array}$ & $c=.14, p<.05$ & $c^{\prime}=.13, p<.05$ & $\begin{array}{l}\mathrm{nt}=.002, \% 95 \mathrm{Cl} \\
{[-.01, .02]}\end{array}$ & Red \\
\hline $\begin{array}{c}\mathrm{H15} \\
(\mathrm{X} 4 \rightarrow \mathrm{M} 1, \mathrm{M} 2,\end{array}$ & $\begin{array}{l}B=-.02 p>.05 \\
B=.03, p>.05 \\
B=.00, p>.05\end{array}$ & $\begin{array}{l}B=.05, p>.05 \\
B=.25, p<.05 \\
B=.11, p>.05\end{array}$ & $\mathrm{C}=.09, \mathrm{p}<.05$ & $c^{\prime}=.09, p<.05$ & $\begin{array}{l}\mathrm{nt}=.006, \% 95 \mathrm{Cl} \\
{[-.02, .03]}\end{array}$ & Red \\
\hline $\begin{array}{c}(\mathrm{X} 4 \rightarrow \mathrm{M} 1, \mathrm{M} 2, \\
\mathrm{M} 3 \rightarrow \mathrm{Y} 4)\end{array}$ & $\begin{array}{l}B=-.02 p>.05 \\
B=.03, p>.05 \\
B=.00, p>.05\end{array}$ & $\begin{array}{l}B=.07, p<.05 \\
B=.21, p<.05 \\
B=.14, p<.05\end{array}$ & $\mathrm{c}=.07, \mathrm{p}<.05$ & $c^{\prime}=.06, p<.05$ & $\begin{array}{l}\mathrm{nt}=.004, \% 95 \mathrm{Cl} \\
{[-.02, .02]}\end{array}$ & Red \\
\hline
\end{tabular}

Bağımsız Değişkenler: Yumuşak başlılık (X4)

Bağımlı değişkenler: Değişim ve meydan okumaya başa çıkma esnekliği (Y1), Sosyal ve ailesel destek (Y2), Ruhsal destek (Y3), Hedef odaklı yaklaşım (Y4)

Aracı Değişkenler: Yüzeysel davranış (M1), Derin davranış (M2) ve Doğal duygular (M3) 


\subsection{5 "Duygusal dengelilik" kişilik tipinin yılmazlık üzerinde etkisinde duygusal emeğin aracı rolüne ait bulgular}

"Duygusal dengelilik" kişilik tipinin sırasıyla yılmazlık alt boyutları üzerindeki etkisinde duygusal emek alt boyutlarının aracı rolü incelendiğinde; bu kişilik tipinin "değişim ve meydan okumaya başa çıkma esnekliği" üzerindeki toplam etkisi ( $c=.04, p>.05$ ), "sosyal ve ailesel destek" üzerindeki toplam etkisi $(c=.00, p>.05)$, "ruhsal destek" üzerindeki toplam etkisi $(c=.05, p>.05)$ ve "hedef odaklı yaklaşım" üzerindeki toplam etkisi ( $c=.03, p>.05$ ) anlamlı değildir (1.Aşama). "Duygusal dengelilik" kişilik tipinin aracı değişkenler olan Yüzeysel davranış $(B=.01, p>.05)$ ve Doğal duygular $(B=.03$, $p>.05)$ üzerindeki doğrudan etkileri anlamlı değilken Derin davranış $(B=.07, p<.05)$ alt boyutu üzerindeki doğrudan etkisi anlamlıdır (2.Aşama) (Tablo 8).

Aracı değişkenlerin "değişim ve meydan okumaya başa çıkma esnekliği" üzerindeki doğrudan etkisi incelendiğinde, Yüzeysel davranışın $(B=.06, p>.05)$ anlamsız, Derin davranış $(B=.18, p<.05)$ ve Doğal duygular $(B=.11, p<.05)$ alt boyutlarının anlamlı etkisi olduğu görülmektedir. Aracı değişkenlerin "sosyal ve ailesel destek" üzerindeki doğrudan etkisi incelendiğinde, Yüzeysel davranışın ( $B=.07, p>.05)$ anlamsız, Derin davranış $(B=.14, p<.05)$ ve Doğal duygular $(B=.11, p<.05)$ alt boyutlarının anlamlı etkisi olduğu görülmektedir. Aracı değişkenlerin "ruhsal destek" üzerindeki doğrudan etkisi incelendiğinde, Yüzeysel davranış $(B=.05, p>05)$ ve Doğal duygular $(B=.11, \mathrm{p}>.05)$ alt boyutlarının anlamsız, Derin davranış $(B=.25, \mathrm{p}<.05)$ alt boyutlarının anlamlı etkisi olduğu görülmektedir. Aracı değişkenlerin "hedef odaklı yaklaşım" üzerindeki doğrudan etkisi incelendiğinde, Yüzeysel davranış $(B=.07, p<.05)$, Derin davranış $(B=.21, \mathrm{p}<.05)$ ve Doğal duygular $(B=.14, \mathrm{p}<.05)$ alt boyutlarının anlamlı etkisi olduğu görülmektedir (3.Aşama) (Tablo 8).

"Duygusal dengelilik" ile tüm aracı değişkenler modele eş zamanlı olarak alındığında (4.Aşama) "duygusal dengelilik" kişilik tipinin "değişim ve meydan okumaya başa çıkma esnekliği" üzerindeki doğrudan etkisi anlamlı değildir ( $c$ '=.01, p>.05). Bu sonuca göre duygusal emeğin aracı rolü olmadığı görülmektedir. Aynı zamanda "duygusal dengelilik" kişilik tipinin "değişim ve meydan okumaya başa çıkma esnekliği" üzerindeki dolaylı etkisi anlamlı olmasına rağmen (nokta tahmini $=.032, \% 95 \mathrm{Cl}[.01$, .05]) diğer şartlar sağlamadığı için aracı etki görülmemektedir (H17: Kabul edilmemiştir). Ayrıca "duygusal dengelilik" kişilik tipinin "sosyal ve ailesel destek" üzerindeki doğrudan etkisi ( $c$ '=-.01, p>.05) ve dolaylı etkisi (nokta tahmini=.013, \%95 $\mathrm{Cl}[-.003, .03])$ anlamlı değildir. Bu sonuca göre duygusal emeğin aracı rolü olmadığı görülmektedir (H18: Kabul edilmemiştir). "Duygusal dengelilik" kişilik tipinin "ruhsal destek" üzerindeki doğrudan etkisi $(c$ '=.03, $p>.05)$ ve dolaylı etkisi (nokta tahmini $=.021$, $\% 95 \mathrm{Cl}[-.001, .05])$ anlamlı değildir. Bu sonuca göre duygusal emeğin aracı rolü olmadığı görülmektedir (H19: Kabul edilmemiştir). "Duygusal dengelilik" kişilik tipinin "hedef odaklı yaklaşım" üzerindeki doğrudan etkisi de anlamlı değildir ( $c$ '=.01, $p>.05)$. Aynı zamanda "duygusal dengelilik" kişilik tipinin "hedef odaklı yaklaşım" üzerindeki dolaylı etkisi anlamlı olmasına rağmen (nokta tahmini $=.039, \% 95 \mathrm{Cl}[.02, .06]$ ) diğer şartlar sağlamadığı için aracı etki görülmemektedir (H20: Kabul edilmemiştir) (Tablo 8). 
Tablo 8: Aracılık analizi sonuçları

\begin{tabular}{|c|c|c|c|c|c|c|}
\hline & $\begin{array}{l}\text { a yolu } \\
(X \rightarrow M)\end{array}$ & $\begin{array}{l}\text { b yolu } \\
(M \rightarrow Y)\end{array}$ & $\begin{array}{l}\text { c yolu } \\
(X \rightarrow Y)\end{array}$ & $\begin{array}{l}\text { c'yolu } \\
\text { Doğrudan } \\
\text { etki }\end{array}$ & $\begin{array}{l}\text { Nokta tahmini } \\
\text { (nt), Cl }\end{array}$ & $\begin{array}{l}\text { Kabu } \\
\text { I } \\
\text { /Red }\end{array}$ \\
\hline $\begin{array}{l}\mathbf{H 1 7} \\
(\mathrm{X} 5 \rightarrow \mathrm{M}, \\
\mathrm{M} 2, \rightarrow \mathrm{M}, \\
\mathrm{Y} 1)\end{array}$ & $\begin{array}{l}B=.01, \mathrm{p}>.05 \\
B=.07, \mathrm{p}<.05 \\
B=.03, \mathrm{p}>.05\end{array}$ & $\begin{array}{l}B=.06, p>.05 \\
B=.18, p<.05 \\
B=.11, p<.05\end{array}$ & $C=.04, p>.05$ & $c^{\prime}=.01, p>.05$ & $\begin{array}{l}\mathrm{nt}=.032, \% 95 \\
\mathrm{Cl}[.01, .05]\end{array}$ & Red \\
\hline $\begin{array}{l}\mathrm{H} 18 \\
(\mathrm{X} 5 \rightarrow \mathrm{M} 1, \\
\mathrm{M} 2, \rightarrow \mathrm{M}, \\
\mathrm{Y} 2)\end{array}$ & $\begin{array}{l}B=.01, p>.05 \\
B=.07, p<.05 \\
B=.03, p>.05\end{array}$ & $\begin{array}{l}B=.07, p>.05 \\
B=.14, p<.05 \\
B=.11, p<.05\end{array}$ & $c=.00, p>.05$ & $c^{\prime}=-.01, p>.05$ & $\begin{array}{l}\mathrm{nt}=.013, \% 95 \\
\mathrm{Cl}[-.003, .03]\end{array}$ & Red \\
\hline $\begin{array}{l}\mathbf{H 1 9} \\
(\mathrm{X} 5 \rightarrow \mathrm{M}, \\
\mathrm{M} 2, \rightarrow \mathrm{M}, \\
\mathrm{Y} 3)\end{array}$ & $\begin{array}{l}B=.01, \mathrm{p}>.05 \\
B=.07, \mathrm{p}<.05 \\
B=.03, \mathrm{p}>.05\end{array}$ & $\begin{array}{l}B=.05, p>.05 \\
B=.25, p<.05 \\
B=.11, p>.05\end{array}$ & $c=.05, p>.05$ & $c^{\prime}=.03, p>.05$ & $\begin{array}{l}\mathrm{nt}=.021, \% 95 \\
\mathrm{Cl}[-.001, .05]\end{array}$ & Red \\
\hline $\begin{array}{l}\mathbf{H 2 0} \\
(\mathrm{X} 5 \rightarrow \mathrm{M} 1, \\
\mathrm{M} 2, \rightarrow \mathrm{M} 3 \\
\mathrm{Y} 4)\end{array}$ & $\begin{array}{l}B=.01, p>.05 \\
B=.07, p<.05 \\
B=.03, p>.05\end{array}$ & $\begin{array}{l}B=.07, p<.05 \\
B=.21, p<.05 \\
B=.14, p<.05\end{array}$ & $C=.03, p>.05$ & $c^{\prime}=.01, p>.05$ & $\begin{array}{l}\mathrm{nt}=.039, \% 95 \\
\mathrm{Cl}[.02, .06]\end{array}$ & Red \\
\hline
\end{tabular}

Bağımsız Değişkenler: Duygusal dengelilik (X5)

Bağımlı değişkenler: Değişim ve meydan okumaya başa çıkma esnekliği (Y1), Sosyal ve ailesel destek (Y2), Ruhsal destek (Y3), Hedef odaklı yaklaşım (Y4)

Aracı Değişkenler: Yüzeysel davranış (M1), Derin davranış (M2) ve Doğal duygular (M3)

\section{Tartışma ve Sonuç}

Yapılan bu çalışmada değişkenler arasındaki ilişkileri incelemek için korelasyon analizi yapılmıştır. Çalışmanın bağımlı değişkeni olan yılmazlık boyutlarından değişime meydan okumayla başa çıkma esnekliği ile dışa dönüklük, yumuşak başlılık, sorumluluk, duygusal dengelilik, deneyime açıklık kişilik tipleri arasında pozitif yönde anlamlı ilişkiler bulunmuştur. Değişimi benimseyerek yeni deneyimlere açık olarak hayatlarına devam edebilme yılmaz bireylerin en önemli özelliği olarak bildirilmektedir (Hegney ve diğ., 2007). Daha fazla dışa dönüklük, yumuşak başlılık, sorumluluk, duygusal dengelilik, deneyime açıklık kişilik özelliklerine sahip bireylerin değişimlerle daha çok başa çıkabildiğini söylemek mümkündür (Riolli ve diğ., 2002). Ayrıca değişime meydan okumayla başa çıkma esnekliği duygusal emek boyutlarından yüzeysel rol yapma, derinden rol yapma, doğal duygular arasında pozitif yönde anlamlı ilişkiler bulunmuştur. Bu durum da çalışanların değişime meydan okuyabilme özellikleri arttıkça daha fazla duygusal emek davranışı sergileyebilmeleri ile açıklanabilir.

Çalışmanın bağımlı değişkeni olan yılmazlık boyutlarından sosyal ve ailesel destek ile dışa dönüklük, yumuşak başlılık, sorumluluk, duygusal dengelilik, deneyime açıklık kişilik tipleri arasında pozitif yönde anlamlı ilişki bulunmuştur. Ayrıca sosyal ve ailesel destek, duygusal emek boyutlarından yüzeysel rol yapma, derinden rol yapma, doğal duygular ile pozitif yönde anlamlı ilişkili bulunmuştur. Çalışanların duygusal emek davranışları sergileme intimalleri arttıkça sosyal çevrelerinden ve ailelerinden alabilecekleri destek algıları ile yılmazlık düzeyleri de artacaktır. Yine yılmazlık boyutlarından ruhsal destek ile dışa dönüklük, sorumluluk, deneyime açıklık kişilik tipleri arasında pozitif yönde anlamlı ilişki bulunmakta fakat yumuşak başlılık, duygusal 
dengelilik arasında ilişki bulunmamaktadır. Benzer olarak Campbell-Sills ve diğ. (2005) da dışa dönüklük ve yılmazlık arasında pozitif yönde anlamlı ilişkiler tespit etmiştir. Bu ilişkiler ile daha dışa dönük, deneyimlere açık, sorumluluk kişilik özelliğine sahip bireylerin daha yılmaz oldukları söylenebilir. Bu durum da dışa dönük kişilerin iyi ilişkiler kurabilmek için yılmazlık özelliklerini geliştirmeleri ve deneyimlere açık kişilerin de yaşadıkları deneyimlerden edindikleri birikimlerle yılmazlık özelliklerinin gelişmesi ile açıklanabilir. Diğer yandan ruhsal destek yılmazlık boyutu ile duygusal emek boyutlarından derinden rol yapma, doğal duygular arasında da pozitif yönde anlamlı ilişki bulunmuştur. Çalışanların daha çok içinden geldiği gibi, göstermesi gereken davranışları rol yapmadan sergileyebilmeleri ruhsal destek boyutunda çalışanların yılmazlık düzeylerini olumlu etkileyecektir. Bu nedenle çalışanların ruhsal sağlıklarını koruyucu stres azaltıcı iş ortamlarının, iş yeri politikalarının uygulanması yerinde olacaktır.

Çalışmanın bağımlı değişkeni olan yılmazlık boyutlarından hedef odaklı yaklaşım ile dışa dönüklük, yumuşak başlılık, sorumluluk, duygusal dengelilik, deneyime açıklık kişilik tipleri ve duygusal emek boyutlarının da tümüyle pozitif yönde anlamlı ilişkili bulunmuştur. Bu durumda dışa dönüklük, yumuşak başlılık, sorumluluk, duygusal dengelilik, deneyime açıklık kişilik özelliklerine sahip çalışanlar hedef odaklı yaklaşım gösteren yılmaz bireyler olarak atfedilebilir. Aynı zamanda bu bireyler yaşantılarında hedeflerine ulaşmak için daha çok duygusal emek sergileyebilmektedir. Deneyime açıklık kişilik tipi ile duygusal emek boyutlarından derinden rol yapma ve doğal duygular arasında pozitif yönde anlamlı ilişkiler bulunmuştur. Yine sorumluluk ile doğal duygular ve yumuşak başlılık ile doğal duygular arasında pozitif yönde anlamlı ilişki bulunmuştur. Benzer olarak Beğenirbaş ve Yalçın (2012) da yaptığı çalışmasında deneyime açıklık kişilik tipi ile duygusal emek boyutlarından derinden rol yapma ve doğal duygular arasında pozitif yönde anlamlı ilişkiler bulmuştur. Austin ve diğ. (2008) yumuşak başlılık kişilik özellikleri gösterenlerin daha çok doğal duygu gösteriminde bulunduklarını bildirmektedir. O halde deneyime açık, sorumluluk kişilik özelliğine sahip çalışanların daha samimi davranışlar içeren doğal duygu gösterimlerinde bulunması mümkündür. Bu nedenle otel işletmelerinde müşterilerle birebir iletişimde bulunacak çalışanların bu özellikler dikkate alınarak istihdam edilmesi ya da mevcut pozisyonlarının neler olacağına karar verilmesi aşamasında bu özelliklerin bilinmesi gerekmektedir.

Değişkenlerin aralarındaki ilişkilerin belirlenmesinden sonra hipotezler test edilmiş, aracılık ilişkileri incelenmiştir. Burada bağımsız değişken olarak kişilik ve alt boyutları olan dışa dönüklük, duygusal dengelilik, deneyime açıklık, sorumluluk, yumuşak başlılık; aracı değişken olarak duygusal emek ve alt boyutları olan yüzeysel rol yapma, derinden rol yapma ve doğal duygular ele alınmıştır. Bağımlı değişken olarak ise yılmazlık ve alt boyutları olan değişim ve meydan okumaya başa çıkma esnekliği, sosyal ve ailesel destek, ruhsal destek ile hedef odaklı yaklaşım kullanılmıştır. Yapılan bu çalışmada, duygusal emeğin derin davranış $(B=.18, p<.05)$ ve doğal duygular $(B=.11, p<.05)$ alt boyutlarının değişim ve meydan okumaya başa çıkma esnekliği yılmazlık özelliği üzerinde anlamlı düzeyde ve olumlu yönde bir etkisi olduğu görülmektedir. Ayrıca duygusal emeğin yüzeysel davranış $(B=.07, p<.05)$, derin davranış $(B=.21, \mathrm{p}<.05)$ ve doğal duygular $(B=.14, \mathrm{p}<.05)$ alt boyutlarının hedef odaklı yaklaşım yılmazlık özelliği üzerinde anlamlı düzeyde ve olumlu yönde bir etkisi olduğu görülmektedir. Benzer olarak Cheung ve Tang (2010), çalışanların doğal duygu gösterimlerinin yılmazlık üzerinde olumlu etkilerinin olabileceğini vurgulamışlardır. Bu olumlu ilişkiler, çalışanların gerçek duyguları ile duygu gösterim kuralları arasında uyum bulunması halinde, diğer bireylere göre bu çalışanların geleceğe dönük pozitif algılarının, yeteneklerine olan inançlarının, motivasyon düzeylerinin ve amaçlar 
belirleyebilme düzeylerinin yüksek olmasıyla açıklanabilir. Ayrıca bu çalışmada, Biçkes ve diğ. (2014)'nın yüzeysel davranışın yılmazlığı pozitif etkilediği sonucundan farklı olarak, yüzeysel davranış, değişim ve meydan okumaya başa çıkma esnekliği, sosyal ve ailesel destek, ruhsal destek yılmazlık özelliklerini etkilememektedir. Ayrıca doğal duygular da ruhsal destek yılmazlık özelliğini etkilememektedir.

Duygusal emeğin derin davranış $(B=.14, p<.05)$ ve doğal duygular $(B=.11$, $p<.05)$ alt boyutlarının sosyal ve ailesel destek yılmazlık özelliği üzerinde anlamlı düzeyde ve olumlu yönde bir etkisi olduğu görülmektedir. Çalışanların derin davranış ve doğal duygular duygusal emek davranışları sergileme düzeyleri arttıkça sosyal çevrelerinden ya da ailelerinden sosyal destek almaya, olumlu ilişkiler kurarak zorlukların üstesinden gelmeye daha yatkın bireyler oldukları söylenebilir. Yapılan bu çalışmada deneyime açıklık, sorumluluk, yumuşak başlılık kişilik tiplerinin duygusal emek üzerinde anlamlı bir etkisinin bulunmadığı belirlenmiştir. Fakat Beğenirbaş ve Yalçın (2012), Diefendorff ve diğ. (2005) ile Austin ve diğ. (2008) yumuşak başlılık kişilik özelliklerine sahip bireylerin doğal duygu gösteriminde daha fazla bulunduklarına dikkat çekmektedir. Otel çalışanlarından beklenen özelliklerin de iletişime açık, anlayışı, alçak gönüllü, paylaşımcı olmak gibi özellikler olması, iletişimin yüksek olduğu pozisyonlarda yumuşak başlılık kişilik özelliklerine sahip bireylerin varlığını gerektirmektedir.

Dışa dönüklük kişilik tipinin duygusal emek alt boyutlarından yüzeysel davranış üzerinde anlamsız, derin davranış $(B=.10, p<.05)$ ve doğal duygular $(B=.10, p<.05)$ alt boyutları üzerinde ise anlamlı düzeyde ve olumlu yönde bir etkisi olduğu görülmektedir. Diefendorff ve diğ. (2005) ise yaptıkları çalışmada dışadönüklük ile derinden rol yapma ile aynı yönde, yüzeysel rol yapma ile ters yönde ilişkiler tespit etmişlerdir. Sosyal bir yapıya sahip olan dışa dönük kişiliğe sahip bireyler, aynı zamanda cana yakın ve konuşkan bireyler olduklarından yüzeysel rol yapmaya daha az intiyaç duymaktadırlar. $\mathrm{Bu}$ özelliğe sahip bireyler, hizmet sunum sürecinde doğal olarak pozitif duygu yaşayabilmektedir (Barrick ve Mount, 2005). Duygusal dengelilik kişilik tipinin duygusal emeğin yüzeysel davranış ve doğal duygular alt boyutları üzerinde anlamlı bir etkisi bulunamamıştır. Duygusal dengelilik kişilik tipinin duygusal emeğin derin davranış $(B=.07)$ alt boyutu üzerinde ise anlamlı düzeyde ve olumlu yönde bir etkisi olduğu görülmektedir. Kiffin-Petersen ve diğ. (2011), Basım ve diğ. (2013) yaptıkları çalışmaların sonuçlarında duygusal olarak dengesiz olan bireylerin yüzeysel rol yapma davranışı eğiliminde olduğunu bildirmektedir. $\mathrm{Bu}$ nedenle duygusal dengesizlik yaşayan bireylerin yüzeysel rol yapma davranışlarından kaynaklanabilecek olumsuzlukları görevlerine yansıtabilecekleri düşünülmektedir.

Deneyime açıklık, sorumluluk, duygusal dengelilik kişilik tiplerinin yılmazlığın değişim ve meydan okumaya başa çıkma esnekliği, sosyal ve ailesel destek, ruhsal destek ve hedef odaklı yaklaşım üzerinde etkisinin bulunmadığı belirlenmiştir. Oysa beş faktörlü kişilik boyutları ile yılmazlık düzeylerinin ölçüldüğü bazı çalışmalarda kişilik boyutlarından deneyime açıklığın yılmazlık düzeyini olumlu yönde etkilediği bildirilmiştir (Campbell-Sills ve diğ., 2006; Çavuşoğlu ve Yalçın, 2017; Fayombo, 2010). Aynı zamanda Çavuşoğlu ve Yalçın (2017) yaptıkları çalışmada, duygusal dengeliliğin yılmazlık düzeyini olumsuz yönde etkilediği sonucuna ulaşmıştır. Ayrıca dışadönüklük, uyumluluk ve sorumluluk kişilik tiplerinin yılmazlık üzerinde anlamlı bir etkisi bulunmadığını ortaya koymuştur. Yumuşak başlılık kişilik tipi; yılmazlığın değişim ve meydan okumaya başa çıkma esnekliği $(c=.11, p<.05)$, sosyal ve ailesel destek $(c=.14$, $p<.05)$, ruhsal destek $(c=.09, p<.05)$ ve hedef odaklı yaklaşım $(c=.07, p<.05)$ yılmazlık alt boyutlarını anlamlı düzeyde ve olumlu yönde etkilemektedir. Yine benzer olarak Friborg ve arkadaşları (2005), yumuşak başlılık ve yılmazlık sosyal destek boyutu 
arasında olumlu yönde ilişkiler bulmuş, yumuşak başlı, işbirliği yapmaya uyumlu kişilerin kolay sosyal ağlar kurabilmeleri ve böylelikle daha yılmaz bireyler olduklarını ifade etmiş̧lerdir. Yılmazlık oluşumunda kişisel faktörler kadar, sosyal çevre faktörlerinin de değerlendirilmesi gerektiğini ifade eden araştırmalar da (Werner ve Johnson, 2004; Williams ve Shepherd, 2016) dikkate alındığında; elde edilen bu sonuçlar, kişilerin gelişme ve sosyalleşme özelliklerinin önemini ortaya çıkarmıştır. Yılmazlık yapısı oluşurken kişisel özelliklerin yanında çevresel destek faktörlerinin de önemli olduğuna ilişkin kanıtlar sunmuştur. Dışa dönüklük kişilik tipinin ise değişim ve meydan okumaya başa çıkma esnekliği ve hedef odaklı yaklaşım yılmazlık alt boyutlarında etkisi bulunmazken, sosyal ve ailesel destek $(c=.09, p<.05)$ ile ruhsal destek ( $c=.15, p<.05)$ yılmazlık alt boyutlarını anlamlı düzeyde ve olumlu yönde etkilemektedir. Olumlu, topluluk içine girmeyi seven, kendine güvenen, sosyal ve girişken olan dışadönük bireyleri; sosyal ve aile çevrelerinden aldıkları destekle yılmazlık düzeylerinin yüksek çıkması muhtemeldir (Çavuşoğlu ve Yalçın, 2017; Çetin ve diğ., 2015).

Deneyime açıklık, sorumluluk, yumuşak başııık, duygusal dengelilik kişilik tiplerinin değişim ve meydan okumaya başa çıkma esnekliği, sosyal ve ailesel destek, ruhsal destek ve hedef odaklı yaklaşım olmak üzere yılmazlığın tüm alt boyutlarına etkisinde duygusal emeğin aracı rolü olmadığı tespit edilmiştir. Dışa dönüklük kişilik tipinin yılmazlık alt boyutlarından değişim ve meydan okumaya başa çıkma esnekliği ve hedef odaklı yaklaşım alt boyutlarına etkisinde duygusal emeğin aracı rolü olmadığı tespit edilmiştir. Diğer yandan dışa dönüklük kişilik tipinin sosyal ve ailesel destek yılmazlık alt boyutu üzerindeki etkisinde ise duygusal emeğin (derin davranış ve doğal duygular) aracı rolü olduğu görülmektedir. Yani dışa dönüklük kişilik özelliğinin sosyal ve ailesel destek yılmazlık özelliği üzerindeki olumlu yönde etkisine duygusal emek (derin davranış ve doğal duygular) aracılık etmektedir. Yüksek dışa dönük kişilik özelliğine sahip bireyler daha fazla derin davranış ve doğal duygular duygusal emek davranışlarını sergilemekte, bu davranışları sergileyen bireyler de sosyal ve ailesel destek yılmazlık özelliğine sahip olmaktadır. Ayrıca dışa dönüklük kişilik tipinin ruhsal destek yılmazlık alt boyutu üzerindeki etkisinde ise duygusal emeğin (derin davranış) aracı rolü olduğu tespit edilmiştir. Yani dışa dönüklük kişilik özelliğinin ruhsal destek yılmazlık özelliği üzerindeki olumlu yönde etkisine duygusal emek (derin davranış) aracılık etmektedir. Yüksek dışa dönük kişilik özelliğine sahip bireyler daha fazla derin davranış duygusal emek davranışları sergilemekte, bu davranışları sergileyen bireyler de ruhsal destek yılmazlık özelliğine sahip olmaktadır. Ruhsal destek özelliği yüksek bireyler sıkıntılardan, zorluklardan kurtulabilmenin yolunu iç dünyalarındaki inanç, yardımseverlik, iyimserlik yoluyla sağlayabilmektedir (Hefferon ve Boniwell, 2014). Bu nedenle bu bireylerin ilişkilerinde daha yardımsever olması, yüz yüze müşteri etkileşiminin yoğun olduğu pozisyonlarda değerlendirilmeleri yararlı olacaktır.

Çalışanların dışadönüklük, sorumluluk, deneyime açıklık kişilik özelliklerine sahip olanların yılmazlık özelliğine de sahip olduğu bilinmekte, bu nedenle özellikle yönetici konumunda istihdam edilecek bireylerin belirtilen kişilik özelliklerine sahip yılmaz bireyler olması tavsiye edilmektedir. Ayrıca duygusal emek sergileyen bireylerin yılmazlık düzeylerinin de etkilendiği bilinmektedir. Bu sonuçlar, kişiliğin ve duygusal emeğin çalışanların yılmazlık düzeylerini etkilediğini ortaya koymaktadır. Bu nedenle çalışanların ruh sağlıklarının korunması için yılmazlık özelliklerini destekleyici olumlu yönetim politikası, adaletli, sosyal etkileşimli bir iş çevresi yaratılmalıdır.

Çalışma, beş yıldızlı otel işletmelerinin çalışanları ile sınırlandırılmıştır. Bu nedenle iki ve üç yıldızlı otel işletmelerinde gerçekleştirilecek benzer çalışmalarda farklı sonuçların çıkması muhtemeldir. Ayrıca turizm sektörü konaklama dışında 
ulaşım, yeme-içme gibi pek çok alanı içermektedir. Farklı turizm çevrelerinde de çalışma kapsamı genişletilebilir. Diğer yandan farklı sektörlerde uygulanabilecek benzer çalışmaların farklı sonuçlar verebileceği öngörülmektedir. Gelecek çalışmalarda mesleki stres, hizmet süresi gibi faktörlerin bireye yüklediği sorumluluk ve artan beklentilere paralel olarak yılmazlık ile arasında ilişkilerin kurulabileceği muhtemeldir. Yılmazlık bireysel farklılıklardan ve bireylerin neleri risk ya da destek kaynağı olarak algılamalarına göre farklılık gösterebileceğinden farklı gruplarda da bu ilişkiler incelenmelidir. Bireylerin sahip olduğu bu özelliklerin değerlendirilmesi yine farklı ölçeklerle ölçülerek yeni çalışmalar literatüre kazandırılabilir.

\section{Kaynaklar}

Ashforth, B. E., ve Humphrey, R. H. (1993), 'Emotional labor in service roles: The influence of identity', Academy of Management Review, 18(1), ss. 88-115.

Atak, H. (2013), 'On-maddeli kişilik ölçeği'nin Türk Kültürü'ne uyarlanması', Nöropsikiyatri Arşivi, 50, ss. 312-319.

Austin, E. J., Dore, T. C., ve O'Donovan, K. M. (2008), 'Associations of personality and emotional intelligence with display rule perceptions and emotional labour', Personality and Individual Differences, 44(3), ss. 679-688.

Barrick, M.R. ve Mount, M.K. (2005), 'Personality Matters: Moving on to More Important Matters', Human Performance, 18, ss. 359-372.

Baron, R. M., ve Kenny, D. A. (1986), 'The moderator-mediator variable distinction in social psychological research: Conceptual, strategic, and statistical considerations', Journal of Personality and Social Psychology, 51(6), ss. 11731182.

Basım, H. N., Beğenirbaş, M., ve Yalçın, R. (2013), 'Öğretmenlerde kişilik özelliklerinin duygusal tükenmeye etkisi: Duygusal emeğin aracılık rolü', Kuram ve Uygulamada Eğitim Bilimleri, 13(3), ss. 1488-1496.

Basım, H. N., ve Beğenirbaş, M. (2012), 'Çalışma yaşamında duygusal emek: Bir ölçek uyarlama çalışması', Yönetim ve Ekonomi: Celal Bayar Üniversitesi Iktisadi ve Idari Bilimler Fakültesi Dergisi, 19(1), ss. 77-90.

Basım, H. N. ve Çetin, F. (2011), 'Yetişkinler için Psikolojik Dayanıklılık Ölçeği'nin güvenilirlik ve geçerlilik çalışması', Türk Psikiyatri Dergisi, 22(2), ss. 104-114.

Beğenirbaş, M., ve Yalçın, R. C. (2012), 'Öğretmenlerin Kişilik Özelliklerinin Duygusal Emek Gösterimlerine Etkileri', Cag University Journal of Social Sciences, 9(1), ss. 47-66.

Benard, B. (1991), 'Fostering resiliency in kids: Protective factors in the family, school, and community', ss. 1-32.

Biçkes, D. M., Yılmaz, C., Demirtaş, Ö., ve Uğur, A. (2014), 'Duygusal emek ile iş tatmini arasındaki ilişkide psikolojik sermayenin aracılık rolü: Bir alan çalışması', Eskişehir Osmangazi Üniversitesi Iktisadi ve Idari Bilimler Dergisi, 9(2), ss. 97-122.

Bleidorn, W., Hopwood, C. J., ve Wright, A. G. (2017), 'Using big data to advance personality theory', Current Opinion in Behavioral Sciences, 18, ss. 79-82.

Burger, J. M. (2004), Personality (Çev. Erguvan Sarıoğlu, I. D.), İstanbul: Kaknüs Yayınları.

Campbell-Sills, L., Cohan, S. L., ve Stein, M. B. (2006), 'Relationship of resilience to personality, coping, and psychiatric symptoms in young adults', Behaviour research and therapy, 44(4), ss. 585-599.

Carver, C. S., ve Connor-Smith, J. (2010), 'Personality and coping', Annual review of psychology, 61, ss. 679-704. 
Cheung, F. Y. L., ve Tang, C. S. K. (2010), 'Effects of age, gender, and emotional labor strategies on job outcomes: Moderated mediation analyses', Applied Psychology: Health and Well-Being, 2(3), ss. 323-339.

Connor, K. M. ve Davidson, J. R. (2003), 'Development of a new resilience scale: The Connor-Davidson resilience scale (CD-RISC)', Depression and anxiety, 18(2), ss. 76-82.

Çavuşoğlu, S., ve Yalçın, M. (2017), 'Banka çalışanlarının psikolojik dayanıklılık düzeyleri ile kişilik özellikleri arasındaki ilişki', Uluslararası Bilimsel Araştırmalar Dergisi (IBAD), 404-415.

Çetin, F., Yeloğlu, H. O., ve Basım, H. N. (2015), 'Psikolojik dayanıklılığın açıklanmasında beş faktör kişilik özelliklerinin rolü: Bir kanonik ilişki analizi', Türk Psikoloji Dergisi, 30(75), ss. 81-92.

Çiğdem, H. Y. (2011), Hizmet işletmelerinde çalışanların kişilik özellikleri ve iç girişimcilik eğilimleri arasındaki ilişkilerin incelenmesi, Yayınlanmamış Yüksek Lisans Tezi, Aksaray Üniversitesi, Sosyal Bilimler Enstitüsü, Aksaray.

Demirbaş, N. (2010), Yaşamda anlam ve yılmazlık, Yayımlanmamış Yüksek Lisans Tezi, Hacettepe Üniversitesi, Sosyal Bilimler Enstitüsü, Ankara.

Demirel, N. (2015), Duygusal emek faktörünün hizmet kalitesine etkisi: Nevşehir' deki dört ve beş yıldızlı otellere yönelik bir araştırma. Yayımlanmamış Yüksek Lisans Tezi, Nevşehir Hacı Bektaş Veli Üniversitesi Sosyal Bilimler Enstitüsü, Nevşehir.

Diefendorff, J. M., Croyle, M. H., ve Gosserand, R. H. (2005), 'The dimensionality and antecedents of emotional labor strategies', Journal of Vocational Behavior, 66(2), ss. 339-357.

Dong, F., Ablah, E., Nelson, C., Shah, S. ve Khan, A. (2013), 'Validation of a modified CD-RISC: including previously unaccounted for resilience variables', Kansas Journal of Medicine, 6(1), ss. 11-20.

Eley, D. S., Cloninger, C. R., Walters, L., Laurence, C., Synnott, R. ve Wilkinson, D. (2013), 'The relationship between resilience and personality traits in doctors: implications for enhancing well being', PeerJ, 1, ss. 3-16.

Eley, D. S., Leung, J., Hong, B. A., Cloninger, K. M. ve Cloninger, C. R. (2016), 'Identifying the dominant personality profiles in medical students: Implications for their well-being and resilience', PloS one, 11(8), ss. 1-16.

Eren, E. (2015), Örgütsel Davranış ve Yönetim Psikolojisi, 16. Baskı, İstanbul: Beta Basım Yayın.

Erickson, R. J., ve Ritter, C. (2001), 'Emotional labor, burnout, and inauthenticity: Does gender matter?', Social Psychology Quarterly, 64(2), ss. 146-163.

Fayombo, G. A. (2010), 'The relationship between personality traits and psychological resilience among the Caribbean adolescents', International Journal of Psychological Studies, 2(2), ss. 105-116.

Friborg, O., Hjemdal, O., Rosenvinge, J. H., ve Martinussen, M. (2005), 'A new rating scale for adult resilience: What are the central protective resources behind healthy adjustment?', International journal of methods in psychiatric research, 12(2), ss. 65-76.

Genç, A. (2014), Psikolojik dayanıklılığın örgütsel bağlılık ve işten ayrılma niyetine etkisi: görgül bir araştırma, Yüksek Lisans Tezi, Başkent Üniversitesi, Sosyal Bilimler Enstitüsü, Ankara.

Gizir, C. A. (2016), 'Psikolojik Sağlamlık, risk faktörleri ve koruyucu faktörler üzerine bir derleme çalışması', Türk Psikolojik Danışma ve Rehberlik Dergisi, 3(28), ss. 113-128.

Goodwin, R. E., Groth, M., ve Frenkel, S. J. (2011), 'Relationships between emotional labor, job performance, and turnover', Journal of Vocational Behavior, 79(2), ss. 538-548. 
Gosling, S. D., Rentfrow, P. J. ve Swann, W. B. (2003), 'A very brief measure of the Big-Five personality domains', Journal of Research in personality, 37(6), ss. 504-528.

Grandey, A. A. (2000), 'Emotional regulation in the workplace: A new way to conceptualize emotional labor', Journal of occupational health psychology, 5(1), ss. $95-110$.

Gucciardi, D. F., Jackson, B., Coulter, T. J., ve Mallett, C. J. (2011), 'The ConnorDavidson Resilience Scale (CD-RISC): Dimensionality and age-related measurement invariance with Australian cricketers', Psychology of Sport and Exercise, 12(4), ss. 423-433.

Gülaydın, M. (2019), Algılanan Örgütsel Destek İle Duygusal Emek Davranışları Arasındaki İlişki Üzerine Bir Araştırma: Afyonkarahisar'daki Beş Yıldızıı Otel İşletmeleri Örneği, Yayımlanmamış Yüksek Lisans Tezi, Afyon Kocatepe Üniversitesi, Sosyal Bilimler Enstitüsü, Afyon.

Güney, S. (2013), Davranış Bilimleri, Geliştirilmiş 7. Baskı, Ankara: Nobel Yayıncılık.

Gürbüz, S. (2019), Sosyal bilimlerde aracı, düzenleyici ve durumsal etki analizleri: IBM SPSS Process Makro Uygulamalı, Örnek veri setleri. Ankara: Seçkin Yayıncılık.

Gürgan, U. (2006), 'Yılmazlık ölçeği (YÖ): Ölçek geliştirme, güvenirlik ve geçerlik çalışması', Ankara Üniversitesi Eğitim Bilimleri Fakültesi Dergisi, 39(2), ss. 4574.

Hayes, A. F. (2018), 'Partial, conditional, and moderated moderated mediation: Quantification, inference, and interpretation', Communication Monographs, 85(1), ss. 4-40.

Hefferon, K. Ve Boniwell, I. (2014), Positive Psychology- Theory, Research and Applications (Çev. Ed. Doğan, T.), Ankara: Nobel Yayınları.

Hegney, D. G., Buikstra, E., Baker, P., Rogers-Clark, C., Pearce, S., Ross, H., King, C. ve Watson-Luke, A. (2007), 'Individual resilience in rural people: a Queensland study, Australia', Rural and remote health, 7(14), ss. 1-13.

Hochschild, A.R. (1983), 'The Managed Heart Commercialization of Human Feeling', University of California Press, Berkeley, 7-35. https://caringlabor.files.wordpress.com/2012/09/the-managed-heart-arlie-russellhochschild.pdf $(23,12,2017)$.

İnanç, B. G. ve Yerlikaya, E. E. (2009), Kişilik Kuramları, Ankara: Pegem Akademi Yayıncılık.

Jung, C. G. (2014), 'The development of personality'. England: Routledge. https://books.google.com.tr/books?id=8mTfBQAAQBAJ\&hl=tr (20.10.2017).

Kamaşak, R. ve Bulutlar, F. (2010), 'Kişilik, Mesleki Tercih ve Performans İlişkisi: Akademik Personel Üzerine Bir Araştırma', Organizasyon ve Yönetim Bilimleri Dergisi, 2(2), ss. 119-126.

Kara, A. U., ve Aydoğan, E. (2017), 'Ahilikte psikolojik sermaye davranışı', Bilig, 80, ss. 217-237.

Karagöz, Y. (2017), SPSS ve AMOS uygulamalı nitel- nicel- karma bilimsel araştırma yöntemleri ve yayın etiği, Ankara: Nobel Yayıncılık.

Karaırmak, Ö. (2006), 'Psikolojik Sağlamlık, Risk Faktörleri Ve Koruyucu Faktörler', Türk Psikolojik Danışma ve Rehberlik Dergisi, 3(6), ss. 129-142.

Kaya, U., ve Serçeoğlu, N. (2013), 'Duygu İşçilerinde İşe Yabancılaşma: Hizmet Sektöründe Bir Araştırma', Çalisma ve Toplum, 36(1), ss. 311-346.

Keleş, Y. (2014), Örgütsel Adaletin Duygusal Emek Üzerindeki Etkisi: Antalya'daki Beş Yıldızlı Otel İşletmelerinde Bir Araştırma, Yayımlanmamış Doktora Tezi, Gazi Üniversitesi, Eğitim Bilimleri Enstitüsü, Ankara.

Kim, J. W., Lee, H. K. ve Lee, K. (2013), 'Influence of temperament and character on resilience', Comprehensive Psychiatry, 54(7), ss. 1105-1110. 
Kumpfer, K. L., ve Summerhays, J. F. (2006), 'Prevention Approaches to Enhance Resilience among High-Risk Youth: Comments on the Papers of Dishion and Connell and Greenberg', Annals of the New York Academy of Sciences, 1094(1), ss. 151-163.

Kiffin-Petersen, S. A., Jordan, C. L., ve Soutar, G. N. (2011), 'The big five, emotional exhaustion and citizenship behaviors in service settings: The mediating role of emotional labor', Personality and Individual Differences, 50(1), ss. 43-48.

Kültür ve Turizm Bakanlığı (2019), 'Turizm Belgeli Tesisler', https://istanbul.ktb.gov.tr/TR-172646/turizm-belgeli-tesisler.html (05.12.2019).

Leung, R., ve Law, R. (2010), 'A review of personality research in the tourism and hospitality context', Journal of Travel \& Tourism Marketing, 27(5), ss. 439-459.

Liu, Y., Wang, Z. H., ve Li, Z. G. (2012), 'Affective mediators of the influence of neuroticism and resilience on life satisfaction', Personality and individual differences, 52(7), ss. 833-838.

Luthans, F. (2011), 'Organizational Behavior: An Evidence-Based Approach', 12. Baskı, New York: The McGraw-Hill Companies. https://bdpad.files.wordpress.com/2015/05/fred-luthans-organizational-behavior-an-evidence-based-approach-twelfth-edition-mcgraw-hill irwin-2010.pdf (02.05.2019).

MacKinnon, D. P., Lockwood, C. M., ve Williams, J. (2004), 'Confidence limits for the indirect effect: Distribution of the product and resampling methods', Multivariate behavioral research, 39(1), ss. 99-128.

Masten, A. S. (2007), 'Resilience in developing systems: Progress and promise as the fourth wave rises', Development and psychopathology, 19(03), ss. 921-930.

McCrae, R. R., ve Costa, P. T. (1987), 'Validation of the five-factor model of personality across instruments and observers', Journal of personality and social psychology, 52(1), ss. 81-90.

McCrae, R. R., ve John, O. P. (1992), 'An introduction to the five-factor model and its applications', Journal of personality, 60(2), ss.175-215.

McShane, S.L. ve von Glinow, M. A. (2016), Örgütsel Davranış, (çev. A. Günsel ve S. Bozkurt), Ankara: Nobel Akademik Yayıncılık.

McCubbin, M., Balling, K., Possin, P., Frierdich, S., ve Bryne, B. (2002), 'Family resiliency in childhood cancer', Family relations, 51(2), ss. 103-111.

Özkalp, E. ve Kırel, Ç. (2010), Örgütsel Davranış, 4.Baskı, Bursa: Ekin Basım Yayın Dağıtım.

Peng, L., Zhang, J., Li, M., Li, P., Zhang, Y., Zuo, X., Miao Y. ve Xu, Y. (2012), 'Negative life events and mental health of Chinese medical students: the effect of resilience, personality and social support', Psychiatry research, 196(1), ss. 138-141.

Pietrzak, R. H., ve Cook, J. M. (2013), 'Psychological resilience in older US veterans: results from the national health and resilience in veterans study', Depression and anxiety, 30(5), ss. 432-443.

Richardson, G. E. (2002), 'The metatheory of resilience and resiliency', Journal of clinical psychology, 58(3), ss. 307-321.

Riolli, L., Savicki, V., ve Cepani, A. (2002), 'Resilience in the face of catastrophe: Optimism, personality, and coping in the Kosovo crisis', Journal of applied social psychology, 32(8), ss. 1604-1627.

Sekaran, U. (2003), 'Research Methods for Business: a Skill-Building Approach', America.http://iaear.weebly.com/uploads/2/6/2/5/26257106/research methods entiree book umasekaram-pdf-130527124352-phpapp02.pdf (20.11.2017).

Şimşek, M. Ş., Akgemci, T. ve Çelik, A. (2001), Davranış Bilimlerine Giriş ve Örgütlerde Davranış, 2. Baskı, Ankara: Nobel Yayın Dağıtım. 
Takma, Ç. ve Atıl, H., (2006), 'Bootstrap metodu ve uygulanışı üzerine bir çalışma 2. güven aralıkları, hipotez testi ve regresyon analizinde bootstrap metodu', Ege Üniversitesi, Ziraat Fakültesi Dergisi, 43(2), ss. 63-72.

Terzi, Ş. (2008), 'Üniversite ögrencilerinin psikolojik dayanıklılıkları ve algıladıkları sosyal destek arasındaki ilişki', Türk Psikolojik Danışma ve Rehberlik Dergisi, 3(29), ss. 1-11.

Tews, M.R. ve Glomb, T.M. (2004), 'Emotional labor and the five factor model of Personality', Cornell University Center for Hospitality Research Paper, http://www.hotelschool.cornell.edu/chr/pdf/showpdf/laborfivefactor.pdf (25.02.2018).

Wharton, A. S. (1999), 'The psychosocial consequences of emotional labor', The Annals of the American Academy of Political and Social Science, 561(1), ss. 158-176.

Werner, E. E. ve Johnson, J. L. (2004), 'The role of caring adults in the lives of children of alcoholics', Substance Use and Misuse, 39(5), ss. 699-720.

Williams, T. A., ve Shepherd, D. A. (2016), 'Building resilience or providing sustenance: Different paths of emergent ventures in the aftermath of the Haiti earthquake', Academy of Management Journal, 59(6), ss. 2069-2102.

Yeni, Z., ve Özler, N. D. E. (2016), 'Kişiliğin duygusal emek üzerinde etkisi var mıdır? özel eğitim ve rehabilitasyon merkezlerinde bir uygulama', Global Business Research Congress, ss. 402-411.

Yeung, S., ve Leung, C. (2007), 'Perception and attitude of Hong Kong hotel guestcontact employees towards tourists from Mainland China', International Journal of Tourism Research, 9(6), ss. 395-407.

Yıldırım, A. ve Şimşek, H. (2013), Sosyal Bilimlerde Nitel Araştırma Yöntemleri, Genişletilmiş 9. Baskı, Ankara: Seçkin Yayıncılık.

Youssef, C. M. ve Luthans, F. (2007), 'Positive organizational behavior in the workplace', Journal of Management, 33(5), ss. 774-800.

Zel, M. (2006), Kişilik ve Liderlik, 2. Baskı, Ankara: Nobel Yayınları.

Zhao, X., Lynch Jr, J. G., ve Chen, Q. (2010), 'Reconsidering Baron and Kenny: Myths and truths about mediation analysis', Journal of consumer research, 37(2), ss. 197-206.

Sayı : $11054618-302.08 .01-$

Konu : Bilimsel ve Egitim Amaçh

\section{LISANSÜSTÜ EĞITIM ENSTITÜSŨ MÜDÛRLÜGŬNE}

Ilgi : $\quad 26 / 09 / 2018$ tarih ve E. 7784 sayılı yazı.

Illgi yazınız ile göndermiş olduğunuz, Enstitünüz Turizm Ișletmeciliği Anabilim Dalı Yüksek Lisans Öğrencisi Süreyya AKCAY'ın, Prof.Dr. Muharrem TUNA'nın danışmanlığında yürüttüğŭ "Kisilik Tiplerinin Yılmazlığa Etkisinde Duygusal Emeğin Aracılık Rolï: Turizm Işletmelerinde Bir Uygulama" adı tez çalışması ile ilgili konu Komisyonumuzun 19.10.2018 tarih ve 04 sayılı toplantısında görüșülmüş olup;

Ilgilinin çalışmasının, ekte gönderilen Başvuru Değerlendirme Raporunda önerilen görüş doğrultusunda yapılması planlanan yerlerden izin alınması koşuluyla yapılmasında etik açıdan bir sakınca bulunmadığına oybirliği ile karar verilmiş ve karara ilișkin imza listesi ekte gönderilmiştir. 